\title{
POLITIKK
}

Please note: The original English language version of this article follows, in its entirety, directly below this Norwegian translation.

\section{Norges reaksjon på ebola: en sammenblanding av altruistiske og sikkerhetsmessige interesser ${ }^{1}$}

\author{
Antoine de Bengy Puyvallée \\ Senter for utvikling og miljø, Universitetet $i$ Oslo
}

\begin{abstract}
Sammendrag
Denne artikkelen utforsker et enkelt giverland, Norge, sine motivasjoner for å bidra til den globale responsen på ebola (2014). Gjennom en granskning av interessene, normene og konteksten som var involvert finner jeg at hjemkomsten av en ebolasmittet frivillig til Norge forårsaket en sterk respons fra regjeringen. Responsen var humanitær i sin natur, men delvis fremstilt som et eksistensielt sikkerhetsproblem, og var dermed drevet av altruistiske og sikkerhetsinteresser: et ønske om å bidra med assistanse $o g$ en ambisjon om å begrense epidemien ved kilden, mens frykt innenriks også ble håndtert. Denne analysen samsvarer med publikasjoner som understreker den sentrale rollen til sikkerhetsinteresser i den globale ebolaresponsen, men antyder samtidig at humanitær motivasjon ikke bør overses. Endelig er mitt argument i denne artikkelen at det teoretiske skillet mellom tilnærminger til global helsesikkerhet som kan beskrives som henholdsvis «statist» og "globalist》 ikke fullstendig dekker kompleksiteten i operasjonaliseringen av begrepet global helsesikkerhet. Jeg innfører derfor ideen om en «universalistisk» forståelse av global helsesikkerhet. Denne forståelsen bruker det globale nivået som referanse for sikkerhet og åpner opp for balansering av realpolitikk og idealpolitikk.
\end{abstract}

Nøkkelord: ebola $\cdot$ global helsesikkerhet $\cdot$ securitization $\cdot$ humanitære tiltak $\cdot$ konstruktivisme 


\section{Introduksjon}

Medisinsk antropolog Charles Rosenberg foreslår at epidemier er dramaturgiske hendelser som utfolder seg i tre akter: samfunn begynner gjerne med en periode med "fornektelse», før situasjonen eskalerer til det punkt at den ikke kan ignoreres lenger. Alvoret er så «gjenkjent» av styringsmakter som gir en forklaring på problemet (setter det inn i en bestemt tolkningsramme), og endelig, setter i gang en offentlig respons (Rosenberg 1989: 3-9). Den norske regjeringens respons på ebolaepidemien som herjet Sierra Leone, Liberia og Guinea i 2014-2015 indikerer en lignende dramaturgi med en veldig rask overgang i oktober 2014 fra "gienkjennelse» til «igangsettelse av respons». Den norske utenriksministerens første pressemelding om ebola ble publisert i april 2014 og tok en nøytral og deskriptiv innfallsvinkel, som uttrykte støtte til arbeidet til den medisinske ikke-statlige organisasjonen Leger uten grenser (UD 2014a). Innen utgangen av juli 2014 ble situasjonen i Vest-Afrika beskrevet som en "stor bekymring", men offentligheten ble forsikret at "antall tilfeller rapportert i Guinea har falt» (UD 2014c). Innen tidlig høst samme år var inntrykket av alvor sterkt økende: situasjonen ble beskrevet som «dramatisk» (UD 2014e) i midten av september og innen 6. oktober 2014 ble den beskrevet som «kritisk» (UD 2014b). Utenriksdepartementet (UD) brukte begrepet "krise» for første gang fire dager senere, 10. oktober 2014 (UD 2014d).

Det at en norsk kvinnelig ansatt i Leger uten grenser (en lege) ble smittet i Sierra Leone spilte en vesentlig rolle i å fremskynde anerkjennelsen av en "krise» og planene for en offentlig respons. Hjemkomsten hennes, tre dager etter at hun ble diagnostisert med ebola 5. oktober, fikk massiv medieoppmerksomhet. Spektakulære bilder av da hun ble innlagt på Ullevål sykehus i Oslo i en lukket seng, eskortert av helsepersonell i fullt beskyttelsesutstyr, førte til overskrifter i norske medier i flere dager og nøret oppunder en frenetisk formidling fra regjeringen (tre pressemeldinger på bare ti dager) (UD 2014b, 2014d, 2014f). Ebola hadde ankommet Norge og det giorde det umulig å fortsette å bagatellisere krisen. Regjeringen annonserte sin beslutning om å sende statlig helsepersonell til et feltsykehus i Moyamba, Sierra Leone, dagen etter at den smittede legen kom til Norge, som del av et tiltak ledet av Storbritannia (Helsedirektoratet 2015a: 5). Videre firedoblet den norske regjeringen støtten til internasjonale tiltak i kampen mot ebola innen en uke etter at hun kom til Norge, fra NOK 77,7 millioner til NOK 329 millioner (UD 2014b, 2014d, 2014f). Videre bidrag hevet budsjettet til NOK 500 millioner i kampen mot ebola (UD 2015a). Tabell 1 gir en oversikt over forpliktelsene kunngjort av det norske Utenriksdepartementet i pressemeldinger. I historisk sammenheng var det norske budsjettet for bekjempe ebola kolossalt: det var mer enn dobbelt så stort som budsjettet allokert til den norske humanitære responsen etter jordskjelvet i Nepal (2015, NOK 230 millioner) (UD 2015b) eller Haiti (2010, NOK 200 millioner) (NORAD 2010).

Jeg søker i denne artikkelen å forstå hva som motiverte utdelingen av disse kolossale ressursene til den internasjonale kampen mot ebola. For å oppnå dette 
Tabell 1. Norske finansielle bidrag i kampen mot ebola annonsert av Utenriksdepartementet i pressemeldinger

\begin{tabular}{|c|c|c|c|c|c|c|c|c|}
\hline & $\begin{array}{l}\text { 3. apr } \\
2014\end{array}$ & $\begin{array}{l}\text { 31. juli } \\
2014\end{array}$ & $\begin{array}{l}\text { 17. sept } \\
2014\end{array}$ & $\begin{array}{l}\text { 6. okt } \\
2014\end{array}$ & $\begin{array}{l}\text { 10. okt } \\
2014\end{array}$ & $\begin{array}{l}\text { 14. okt } \\
2014\end{array}$ & $\begin{array}{l}\text { 5. des } \\
2014\end{array}$ & $\begin{array}{l}\text { 26. mars } \\
2015\end{array}$ \\
\hline $\begin{array}{l}\text { Tilleggsbidrag annonsert } \\
\text { (i millioner NOK) }\end{array}$ & 4 & 15 & 58,7 & 106,3 & 70 & 75 & * & $* *$ \\
\hline $\begin{array}{l}\text { Totalt beløp lovet } \\
\text { (i millioner NOK) }\end{array}$ & 4 & 19 & 77,7 & 184 & 254 & 329 & 334 & 500 \\
\hline
\end{tabular}

* Pressemeldingen fra 5. desember legger ut om planene for prøveprosjekter for vaksinering og oppsummerer budsjettet som ble allokert til ebolakrisen.

${ }^{\star \star}$ Den siste pressemeldingen i mars 2015 oppsummerer generelt Norges finansielle primærbidrag i kampen mot ebola.

analyserer jeg den norske regjeringens forståelse av det politiske problemet (ebolakrisen), undersøker agendaen og målene som ledet til lanseringen av en offentlig respons. Så sammenligner jeg motivasjonene i agendasettingen med verdiene i den offentlige kommunikasjonen som legitimerte intervensjonen. Min påstand er at hjemkomsten av en syk helsearbeider ledet til en endring i forståelse av ebola fra en forståelse som la vekt på det humanitære problemet til at det også ble forstått som en sikkerhetstrussel, noe som rettferdiggiorde mobiliseringen av eksepsjonelle ressurser (Lakoff 2017: 149; McInnes 2016: 381).

\section{Teoretisk grunnlag}

Noen forskere innen International relations har det siste tiåret tatt en kritisk tilnærming til begrepet global helsesikkerhet (Davies 2008, 2010b; Davies, Kamradt-Scott \& Rushton 2015; Elbe 2010; McInnes 2014; Rushton 2011; Rushton \& Youde 2015). Fundert i securitization-teori og sosial konstruktivisme (McInnes \& Lee 2006, 2012; McInnes \& Rushton 2011), sikter deres tilnærming mot å forstå hvordan og hvorfor global helse (eller tilfeller av utbrudd) blir oppfattet og presentert som sikkerhetsspørsmål. De analyserer også hva slags konsekvenser securitization (det vil si innrammingen av epidemier som eksistensielle sikkerhetstrusler) av global helse innebærer (McInnes \& Rushton 2010). For å operasjonalisere denne forskningsagendaen bør man undersøke verdiene, interessene, agendaene og maktrelasjonene som underbygger definisjonen av helsetrusler og samfunnets respons på disse (McInnes \& Lee 2012: 4-5; Davies, Kamradt-Scott \& Rushton 2015: 10-11). Det er det jeg gjør i sammenheng med den norske responsen på ebola.

Forskere innen global helsesikkerhet tenderer mot å introdusere en uforenelig dikotomi i motivasjonen til aktører når de engasjerer seg i helsesikkerhet: man er enten drevet av sikkerhetsformål (realpolitikk) eller av utvikling og humanitære interesser (idealpolitikk) - men ikke begge samtidig. Sara Davies, for eksempel, skiller mellom en «statist» (altså å ta staten som referansepunkt for sikkerhet) og en "globalist» 
(det vil si å ta individet som referansepunkt for sikkerhet) tilnærming til global helsesikkerhet, selv om hun anerkjenner at de to tilnærmingene kan overlappe i noen få tilfeller (Davies 2008). På den ene siden har de fleste studier som analyserer «statist» operasjonalisering av helsesikkerhet konkludert med at giverlands sikkerhetsinteresser (realpolitikk) er dominerende (Brown \& Stovea 2014: 305; Lakoff 2008: 59; Rushton 2011: 780; Davies 2010b: 1177; Aldis 2008: 373). Dette indikerer at prosjekter som sikter mot å forbedre global helsesikkerhet ofte er implementert med utgangspunkt i utenrikspolitiske prinsipper, som dermed reflekterer nasjonale interesser istedenfor ideer om solidaritet (Thieren 2007: 219). Av den grunn bekymrer mange seg over at prioritering av helsesikkerhetstiltak fører til en flytting av ressurser vekk fra utviklingslands hovedinteresser, det vil si problemer som allerede (og ikke potensielt) har katastrofale helsekonsekvenser (Rushton 2011). Med Davies sine ord, tiltak for å motvirke globale helsetrusler «kan raskt kjøre seg fast i egeninteresse» når «bistand gis til utviklingsland for å hjelpe dem med “å fikse' helseinfrastrukturen deres fordi dette på lang sikt beskytter Vesten og stater som for øyeblikket er "sikre' fra disse patogenene» (Davies 2010b: 1177). På den annen side springer "globalist»-tilnærmingen til global helsesikkerhet ut av mer kritisk anlagte sikkerhetsstudier og forsøker å forflytte referansepunktet i sikkerhet fra staten til individet. Dette perspektivet har sine røtter i kosmopolitiske ideer om utvikling, global rettferdighet og solidaritet. Det privilegerer dermed et «omsorgsetos» over et «sikkerhetsetos» (Brown \& Stovea 2014: 304; se også: Adams, Novotny \& Leslie 2008: 304). Helsesikkerhet blir dermed et hovedtrekk ved spørsmålet om menneskehetens sikkerhet, i tillegg til et instrument for å adressere andre sikkerhetsproblemer for enkeltpersoner (Elbe 2010: 108).

Ebolaepidemien i 2014-2015 som smittet over 28000 mennesker og drepte mer enn 11000 (WHO 2016a) har blitt analysert som en global krise. Dette er fordi den ble presentert som en internasjonal sikkerhetstrussel etter at smittede helsearbeidere returnerte til sine hjemland, noe som førte til spredning av viruset over hele verden (McInnes 2016; Lakoff 2017: 151). For eksempel, etter at syke leger og sykepleiere returnerte til USA ble FNs sikkerhetsråd enige om en resolusjon som klassifiserte ebola som en "trussel for internasjonal fred og sikkerhet» (UNSC 2014). Resolusjonens hovedformål var å fremheve de ulike formene for risiko som sprang ut av ebolakrisen for dermed å mobilisere verdenssamfunnet, koordinere tiltak og inspirere til en samlet innsats for å begrense spredning av epidemien (McInnes \& Rushton 2011). Analyser tilsier at en «statist»-tilnærming til global helsesikkerhet dominerte under ebolakrisen, altså at den globale responsen var dominert av vestlige lands sikkerhetsinteresser (Roemer-Mahler \& Rushton 2016). Securitization av krisen førte til alvorlige etiske problemstillinger, som mobiliseringen av uvanlig store finansielle ressurser $\mathrm{i}$ et korttidsperspektiv for å begrense epidemien - på bekostning av langtidsmål som for eksempel gjenopprettelse av helsesystemer (Huang 2014), involvering av militæret (McInnes 2016; Kamradt-Scott et al. 2015) og fremskyndelse av testing av eksperimentelle behandlingsmetoder og vaksiner (Roemer-Mahler \& Elbe 2016). Noen argumenterer 
også for at securitization flyttet fokus vekk fra en rettferdig fordeling av skyld og ansvar (Honigsbaum 2017; Kamradt-Scott 2016).

I denne artikkelen argumenterer jeg at den norske responsen til ebola blandet sikkerhetsinteresser og humanitære ambisjoner, men kom til å bli dominert av sikkerhetsbekymringer etter hjemvendelsen av en syke helsearbeider. Mer generelt argumenterer jeg for at analysen av den globale responsen på ebola har tendert mot å bli redusert til et fokus på statsinteresser, maktrelasjoner eller konsekvensene av en securitization av krisen. Denne analysen har i stor grad utelatt rollen internasjonal identitet og verdier har spilt i utviklingen av slik utenrikspolitikk (Reus-Smit 1999). Ifølge Alexander Wendt (1999: 139) er utenrikspolitikk utarbeidet ved å ta med i beregningen interesser, men også kontekst (det vil si materielle forhold, for eksempel hjemkomsten til en helsearbeider), og normer (som springer ut av ideer og identitet, for eksempel tolkningsrammen og rollen til humanitær bistand). Som en av de første til å gå gjennom motivasjonene som styrer et enkelt giverland respons på ebola, ønsker jeg å vise et perspektiv som tar med i beregningen kompleksiteten av disse motivasjonene. Norge er et interessant case-studium av to grunner. For det første var Norge en innflytelsesrik aktør under ebolakrisen og bidro for eksempel til ebolatiltakene til Verdens helseorganisasjon (WHO) på tilnærmet likt nivå med Storbritannia eller Tyskland. ${ }^{2}$ For det andre settes Norge ofte inn i en tolkningsramme som en "humanitær stormakt» (De Carvalho \& Sande Lie 2015: 60) hvor humanitær bistand ofte framstår som en altruistisk gest og en viktig del av landets utenrikspolitikk (Stokke 1989: 172; Leira 2007). Dette har potensiale til å utfordre ideen om en sikkerhetsdrevet respons på ebolakrisen. Til slutt konkluderer jeg denne artikkelen med et teoretisk poeng ved å argumentere at forskjellen mellom «statist»- og «globalist»-perspektiver på global helsesikkerhet ikke bidrar med det analytiske verktøyet vi trenger for å forstå kompleksiteten bak motivasjonen som drev Norges respons på krisen. Jeg oppfordrer dermed til å etablere en tredje analytisk kategori som jeg kaller «universalistisk» og som bruker det globale nivå som referansepunkt for sikkerhet. Dette åpner opp for en forståelse av global helsesikkerhet som både sikkerhetspolitikk og humanitær politikk.

\section{Metoder}

Jeg trekker i denne artikkelen på grundig analyse av relevante, offentlige policydokumenter, en gjennomgang av relevant forskningslitteratur og 18 delvis strukturerte intervjuer, utført i perioden april til desember 2016. Jeg intervjuet 13 byråkrater fra departementer og direktorater som var involvert i planleggingen av tiltaket, to leger ved Helse Bergen som bidro til tiltaket og tre spesialister på norsk global helseog utenrikspolitikk. Jeg sammenlignet resultatene oppnådd fra de ulike metodene for å forsikre meg om pålitelige og holdbare resultater (triangulering) (Lamont 2015: 79). Gitt sensitiviteten til temaet jeg diskuterer her og det lille miljøet til aktørene

${ }^{2}$ Data samlet av forfatteren fra WHOs offisielle statistikk (WHO 2016b). 
som var involvert, har jeg valgt å anonymisere data innhentet fra intervjuene og indikerer dermed bare informantens opphavsinstitusjon.

\section{Ebola: En kamp mot tiden for å redde liv og en tikkende bombe for Norges sikkerhet og regjeringens legitimitet}

21.oktober 2014. To uker har gått siden hun kom tilbake til Norge, den frivillige som ble smittet av ebola var nå utenfor fare og utskrevet fra sykehuset. Hun uttalte noen få ord under en pressekonferanse som siden ble gjentatt av helseministeren i hans tale til Stortinget: «Klokka tikker, dødstallene stiger. Vi må handle, og vi må handle nå». ${ }^{3}$ I den neste delen av denne artikkelen vil jeg vise at dersom regjeringen oppfattet den humanitære situasjonen som bekymringsverdig, så anså de også ebola som en tikkende bombe, en potensiell trussel mot Norges sikkerhet og regjeringens egen legitimitet.

\section{«En moralsk forpliktelse å hjelpe»: Norge, en «do-gooder»}

Nordmenn har tradisjonelt presentert humanitær bistand og utviklingshjelp som en moralsk forpliktelse. Olav Stokke konkluderer i en studie av opphavet til norsk bistandspolitikk at kjerneverdiene og normene i det norske samfunnet ble mobilisert for å presentere bistand som altruistisk politikk. Disse verdiene inkluderte velferdsstatsideologien (som forutsetter en stor, sterk og intervenerende stat), den kristne filosofien om universelt brorskap (noe som leder til en moralsk forpliktelse til å være del av internasjonal solidaritet) og en sterk tiltro til menneskerettsargumenter (Stokke 1989: 172). Mer nylig har Terje Tvedt presentert norsk bistandspolitikk som resultatet av et godhetstyranni eller et «do-gooder-regime» som var «organisert rundt og søkte legitimitet fra den grunnleggende maksimen - det er moralsk korrekt for velstående folk å gi noe av sin velstand til folk som har veldig lite» (Tvedt 2007: 621). Denne tolkningsrammen førte til at nordmenn uttrykte et høyt nivå av støtte til humanitær bistand og det var enighet om å se slik bistand som et "direkte uttrykk for moralsk dyd» (Leira 2007: 10). Dermed ble det assosiert med et renhetsideal. En ekspert på norsk utviklingspolitikk sa: "Vi [nordmenn] har en forestilling om oss selv som frelsere på en måte - «the do-gooders». Det er i stor grad en fortelling om norsk intervensjon i utlandet, spesielt hvis slik intervensjon er finansiert av bistandsbudsjettet». ${ }^{4}$ Det former også landets rykte utenriks, der Norge - ofte sammen med de andre nordiske landene - blir klassifisert som "god makt» (De Carvalho \& Sande Lie 2015: 56), «moralske stormakter» (Dahl 2005: 895), "globale, gode samaritanere» (Brysk 2009) eller «humane internasjonalister» (Lancaster 2007: 190).

I tråd med denne tradisjonen fremstilte den norske regjeringen ebolaepidemien primært som en humanitær krise som landet var moralsk forpliktet til å adressere: «Norge og andre ressurssterke land $m a ̊$ bidra til at hjelpen skaleres opp ${ }^{5}$ erklærte

\footnotetext{
${ }^{3}$ Bent Høie i Stortinget (2014: 370).

${ }^{4}$ Intervju med en ekspert på norsk utviklingspolitikk, 3. november 2016.

${ }^{5}$ Bent Høie i Stortinget (2014: 370, kursiv lagt til).
} 
for eksempel helseministeren til Stortinget da han introduserte det norske bidraget til globale tiltak i kampen mot ebola. Flere av mine informanter bekreftet at ønsket om å gjøre noe godt var en sentral drivkraft i regjeringens reaksjon. "Jeg tror det sitter ganske dypt i oss at vi må forsøke å bidra. Ikke for å få noe tilbake, men som et rikt land ser vi det som en del av kulturen vår å bidra med det vi kan" ${ }^{6}$ fortalte en seniorbyråkrat fra Helsedirektoratet meg. En rådgiver fra Helsedepartementet husket at «det var en type naiv tanke om at dette kunne hjelpe på et slags høyere nivå, giøre kloden generelt til et bedre sted. Jeg tror det er en måte mange folk tenkte på, også i regjeringsinstitusjoner». ${ }^{7}$ En kilde fra Helsedepartementet husker at hjemkomsten til den norske helsearbeideren og hennes budskap om solidaritet dagen hun ble utskrevet, kastet lys over den humanitære situasjonen i Vest-Afrika og fremprovoserte et sterkt ønske blant offentligheten om å "gjøre noe». ${ }^{8}$ Dette skapte press på de som styrte landet til å utøve landets moralske plikt gjennom en humanitær respons. Regjeringen søkte å adressere offentlighetens krav ved å fokusere egen offentlig kommunikasjon på det humanitære aspektet ved responsen. Da Helsedirektoratets pressemelding presenterte Norges primærbidrag til de internasjonale tiltakene mot ebola (etablering av et feltsykehus i Sierra Leone) ble det lagt strategisk vekt på de frivillige, som ble brukt som et verktøy for å understreke verdier som uselviskhet, solidaritet og oppofring (Helsedirektoratet 2015b). Det var ikke så mye prosjektets innhold og formål, som dets altruistiske intensjoner som ble understreket, illustrert ved helsearbeidernes personlige fortellinger. Denne måten å ramme inn situasjonen resonnerte sterkt med den norske identiteten og var instrumentell i legitimeringen av den norske responsen, som en informant ved Helsedepartementet også antydet: "Å ha følelsen av at du bidrar tror jeg er viktig. Det er det media solgte - og det er sant nok!» ${ }^{9}$

\section{Regjeringens sikkerhetsformål: Å beskytte Norge og håndtere befolkningens frykt}

Da den smittede frivillige kom hjem ledet det ikke bare til en overstrømmende solidaritet og godvilje, men ga også troverdighet til muligheten for en ukontrollert spredning av epidemien til Norge. Ettersom ebola dermed ble ansett som en trussel mot landet ønsket regjeringen ikke bare å utføre en moralsk forpliktelse gjennom bistand, men også å beskytte den norske befolkningen ved å bidra til internasjonale tiltak mot spredningen av epidemien. I tillegg fikk helsemyndighetene mulighet til å vise at de hadde kontroll på situasjonen, legitimere deres egen posisjon og håndtere befolkningens frykt.

\section{Ebola, en sikkerhetstrussel som måtte begrenses ved kilden}

Returen av den smittede helsearbeideren samt foruroligende epidemiologiske prognoser styrket bekymringen blant helsemyndighetene (USAs Centers for Disease

\footnotetext{
${ }^{6}$ Intervju, ansatt ved det norske Helsedirektoratet, 29. september 2016.

${ }^{7}$ Intervju, ansatt ved det norske Helsedepartementet 30. oktober 2016.

${ }^{8}$ Intervju, ansatt ved det norske Helsedepartementet 30. oktober 2016.

${ }^{9}$ Intervju, ansatt ved det norske Helsedepartementet 30. oktober 2016.
} 
Control anslo at det ville bli mellom 500000 og 1,4 millioner tilfeller tre måneder senere (CDC 2014)). En seniorbyråkrat ved Helsedirektoratet husker det slik:

Vi hadde den siste pandemien nært i minne - H1N1 - det var ikke lenge siden! Og den rammet Norge på et tidspunkt ganske hardt. Vi vet jo at vi kommer til å få noe alvorlig en eller annen gang. Flere av oss tenkte: «Er det nå det starter?» Vi var veldig nervøse tidlig den høsten. ${ }^{10}$

Gjentatte ganger ble inntrykket av en overhengende trussel berettiget i intervjuene mine med det samme argumentet: Globalisering hadde økt vår sårbarhet for smittsomme sykdommer ved at sammenkoblingene $\mathrm{i}$ verden hadde blitt utvidet og forsterket. Byråkrater fra ulike departementer og direktorater som var involvert i responsplanleggingen fortalte meg for eksempel «Vi mener det er fakta at [...] verden krymper raskt, og derfor kan en sykdom i en del av verden bli et problem her hjemme», ${ }^{11}$ "Infeksjoner kjenner ingen grenser», ${ }^{12}$ "Epidemier sprer seg over grenser, [...] du vet ikke når de kan komme til Norge!» ${ }^{13}$ og "Tross alt kjenner ikke sykdommer grenser. Hvis det finnes en måte de kan bli overført fra et sted til et annet, så vil de gjøre det!» ${ }^{14}$ Kun en av informantene mine, en offentlig helsespesialist i Helsedepartementet, var kritisk til dette argumentet og foreslo istedenfor at den type risiko som ebolaepidemien i Vest-Afrika utgjorde var overvurdert:

Det ble også sagt: «Vi lever i en global landsby, det vil påvirke oss. Av den grunn må vi må bruke norske penger fra Helsedepartementet, fordi vi kan bli påvirket hvis de kan bli påvirket» - noe som ikke er sant! [...] Det var ganske usannsynlig at dette [ebola] ville ha stor innvirkning her [i Norge]. ${ }^{15}$

Norske myndigheters vilje til å anerkjenne ebola som en trussel ved å trekke på argumentet «sykdommer kjenner ingen grenser» er ikke overraskende. Forskere innen International relations har argumentert at fremveksten av et nytt globalt helsesikkerhetsregime siden 1990-tallet i stor grad ble fasilitert av en utstrakt bruk av dette argumentet (Davies, Kamradt-Scott \& Rushton 2015; McInnes \& Lee 2012; Weir 2014; Nunes 2014; de Bengy Puyvalléke \& Kittelsen forthcoming). De har også oppdaget at dette argumentet spilte en sentral rolle i å gjøre ebolakrisen til et globalt problem og nøret opp under kollektiv handling (McInnes 2016:386). I tillegg har oppfatningen om en grenseløs verden direkte politiske konsekvenser som var veldig synlige i den norske responsen på ebola. Argumentet ble oversatt til en norm for rask intervensjon for å begrense utbruddet ved kilden, noe som gjorde internasjonale tiltak til del i førsteprioriteten i nasjonale beredskapsplaner (Rushton 2011; Davies, Kamradt-Scott \& Rushton 2015). Norske myndigheter ser ut til

\footnotetext{
${ }^{10}$ Intervju, ansatt ved det norske Helsedirektoratet, 10. november 2016.

${ }^{11}$ Intervju, diplomat ved det norske Utenriksdepartementet, 30. september 2016.

${ }^{12}$ Intervju, ansatt ved det norske Folkehelseinstituttet, 13. september 2016.

${ }^{13}$ Intervju, ansatt ved det norske Forskningsrådet, 28. september 2016.

${ }^{14}$ Intervju, ansatt ved det norske Helsedepartementet, 28. september 2016.

${ }^{15}$ Intervju, ansatt ved det norske Helsedepartementet, 30. oktober 2016.
} 
generelt å ha adoptert en slik proaktiv, intervensjonsorientert tilnærming. En informant ved Folkehelseinstituttet argumenterte for eksempel at «det er et klart ansvar for nasjonale folkehelseinstitutter å jobbe internasjonalt når det gjelder infeksjonsbegrensning», ${ }^{16}$ fordi bare en proaktiv politikk kan effektivt utføre Helsedepartementets mandat om å sikre "samfunnets sikkerhet og beredskap når det gjelder helse og helsesektoren» (Helsedirektoratet 2016). En rådgiver fra Helsedepartementet foreslår intet mindre enn at:

Vi har lenge argumentert for behovet for å se på den internasjonale dimensjonen. Handling tatt i en region [...] vil ha innvirkning på hva slags tiltak som er nødvendige å utføre på det nasjonale nivået - det er det som er utgangspunktet for vår tenkning i slike kritiske situasjoner. ${ }^{17}$

\section{Håndtering av en skremt offentlighet}

I tillegg til helsemyndighetenes «ansvar for å beskytte [deres] egen sivilbefolkning» ${ }^{18}$ fra farlige patogener, utgjør epidemier en alvorlig utfordring både for samfunn og stat. På den ene siden kaster epidemier lys over underliggende verdier og forsterker sosiale predisposisjoner, som for eksempel motstand mot konflikt i staten eller mellom ulike grupper (Rosenberg 1989: 2). Gamle sår fra år med borgerkrig og ustabilitet i de rammede landene åpner seg med epidemier, noe som spesielt tar form av konspirasjonsteorier og mistro til styresmakter (Kamradt-Scott et al. 2015). På den annen side fører utbrudd til en hel del press på staten, som holdes ansvarlig for måten den håndterer krisen, både av nasjonens borgere og av verdenssamfunnet. Styresmaktene og helsemyndighetene risikerer at det stilles spørsmål ved deres legitimitet og at de mister livsviktig tillit de har hos befolkningen (Roalkvam \& Jani 2013: 115-17). Det verste som kan skje for en regjering er selvfølgelig at den mislykkes i å beskytte befolkningen og begrense utbruddet, men en overreaksjon kan også kreve mye av regjeringens legitimitet (Lakoff 2008: 40-42). Epidemier er derfor tikkende bomber som det er vanskelig å finne en passende måte å håndtere.

Når det gjelder ebolaepidemien mener jeg at de spektakulære bildene av den frivillige kvinnens hjemkomst førte til en visuell securitization av krisen (Hansen 2011: 569; McDonald 2008), noe som førte til at holdninger i norsk offentlighet endret seg fra neglisjering og en relativ likegyldighet (Nunes 2016) til en blanding av frykt og medfølelse. Med andre ord styrket disse bildene ebolatrusselens troverdighet (McInnes \& Rushton 2011: 118; Balzacq 2005: 181) noe som førte til en oppfatning av epidemien som et direkte sikkerhetsproblem for Norge. Følgelig måtte regjeringen adoptere en omhyggelig kommunikasjonsform for å håndtere opinionen. De insisterte for eksempel på den lave sannsynligheten for at epidemien ville spre seg til Norge (selv om mange i administrasjonen mente dette kunne endre seg til å bli en avorlig trussel). Den norske regjeringen måtte også demonstrere at

\footnotetext{
${ }^{16}$ Intervju, ansatt ved Folkehelseinstituttet, 13. september 2016.

${ }^{17}$ Intervju, ansatt ved det norske Helsedepartementet, 28. september 2016.

${ }^{18}$ Intervju, ansatt ved det norske Helsedirektoratet, 5. april 2016.
} 
de var aktive og hadde kontroll på situasjonen. De annonserte beslutningen om å sende statlige helsearbeidere til Sierra Leone dagen etter at den syke frivillige vendte hjem (Helsedirektoratet 2015a: 5) og fremskyndet lanseringen av et prosjekt forberedt siden sensommeren 2014. Dette førte til at en seniorrådgiver ved Helsedepartementet konkluderte at:

Det var nødvendig at alle politikerne ble oppfattet som aktive. Handlekraft, heter jo det på norsk [...] Dette ble jo oppfattet som en stor trussel i VestAfrika, skulle vi ikke gjøre noe? Vi kunne ikke sitte her og gjøre ingenting, så istedenfor måtte vi gjøre noe, og hva kunne vi gjøre? Vi sendte ut folk for å gjøre noe! Jeg tror ikke resultatet en gang betydde noe! ${ }^{19}$

Vitterlig ble ikke resultatene fra feltsykehusprosjektet i Sierra Leone diskutert i den offentlige debatten i Norge, selv om de var ganske skuffende. Behandlingsfasilitetene, som stod åpne i tre og en halv måned og som hadde en kapasitet på 100 senger (og som kostet intet mindre enn 110 millioner kroner for Norge) behandlet kun 33 ebolapasienter (hvorav 18 døde) (Helsedirektoratet 2015a: 50). Mitt argument er at Norge på denne måten oppførte seg som en «do-gooden» under ebolakrisen, «en som gjør ting de tror vil hjelpe andre folk, selv om disse folkene ikke nødvendigvis oppfatter bidragene deres som hjelpsomme». ${ }^{20}$

I tillegg, når regjeringen måtte «gjøre noe» for å legitimere seg selv og bygge tillit måtte de samtidig overbevise offentligheten om at denne proaktive politikken ikke også ville føre til smitte av helsearbeiderne som ble sendt til utlandet. I egen kommunikasjon fokuserte derfor helsemyndighetene på den humanitære siden ved tiltaket, men de fokuserte også på tiltakets sikkerhet. Bilder av helsearbeidere i beskyttelsesutstyr ble nyttige i så sammenheng, siden de både illustrerte faren - og dermed legitimiteten ved preventiv politikk for å beskytte Norge - og omsorgen gitt til de som led i Vest-Afrika (Pallister-Wilkins 2016).

\section{Solidaritet og/eller sikkerhet? Delvis securitization av Norges ebolarespons}

Jeg har vist at den syke helsearbeiderens hjemkomst til Norge på en enestående måte gjorde pågående humanitære krisen i Sierra Leone synlig, men at det også indikerte en foruroligende nærhet til trusselen. Det førte til en sterk statlig respons, som blandet ulike formål og verdier: på den ene siden resonnerte altruisme og omsorg for de som led med Norges nasjonale identitet og landets humanitære tradisjon; på den andre siden reflekterte sikkerhetsinteresser og egeninteresse et narrativ som koblet globalisering sammen med økt sårbarhet og en alvorlig risiko for at panikk kunne spre seg blant befolkningen. (Brown \& Stovea 2014: 304; Davies 2008). Det norske Helsedirektoratet kom til en lignende konklusjon i en rapport om håndteringen

\footnotetext{
${ }^{19}$ Intervju, ansatt ved det norske Helsedepartementet, 30. oktober 2016.

${ }^{20}$ Cambridge Dictionary Online (oversatt fra engelsk), http://dictionary.cambridge.org/dictionary/ english/do-gooder
} 
av ebolakrisen. Der stadfestet de at «motivasjonen for det norske bidraget på denne måten både var humanitært og selvtjenende» (Helsedirektoratet 2015a: 50). En informant fra samme institusjon forklarte denne uttalelsen ved å beskrive ebolaresponsen som «en kombinasjon man ser i mange situasjoner for øyeblikket: en del humanitær bistand, som er veldig viktig, balansert med spørsmål om sivil beredskap». ${ }^{21}$ Uten tvil hadde den norske regjeringen flere grunner for å bidra til internasjonale prosjekter $\mathrm{i}$ kampen mot ebola. Likevel kommer det frem av mine intervjuer at «balansen» mellom disse ulike motivene ser ut til å ha forskjøvet seg mot den delen av responsen som handlet om egeninteresse i løpet av krisens utvikling, slik det kommer frem fra en kilde i Direktoratet for samfunnssikkerhet og beredskap:

Jeg tror vi startet med ideen om å prøve og hjelpe folk som led i Vest-Afrika. Men [...] muligheten for at det ville spre seg til Europa og USA gjorde [selvfølgelig] noe med regjeringens vilje til å gjøre noe. Det er jeg sikker på! ${ }^{22}$

I motsetning til utlegninger som argumenterer for at ebolakrisen ble presentert som en eksistensiell krise [securitized] (Huang 2014), det vil si at epidemien ble ansett som en eksistensiell trussel, argumenterer jeg for at Norge er et eksempel på «delvis securitization» (McInnes \& Rushton 2011: 127). For Colin McInnes og Simon Rushton er securitization et "kontinuum» og kan derfor være «delvis»: «forskjellige deler av publikum vil plassere problemet på ulike steder på et spektrum mellom normalitet og eksistensiell trussel» (Ibid: 128, oversatt fra engelsk). En konflikt mellom Helse Bergen som hadde ansvar for rekruttering av medisinsk personell til feltsykehuset etablert i Sierra Leone og Helsedirektoratet, som var leder for prosjektet, tyder på ulike tilnærminger til responsen og en gradvis bevegelse i retning av økt securitization. Uenigheten mellom de to institusjonene kom spesielt til syne når det gjaldt prosjektets avslutning. Regjeringen ville avslutte prosjektet så fort som mulig, altså når utbruddet fremsto som under kontroll og ikke lenger var en eksistensiell trussel for Norge: «vårt mål var å reise inn og så ut, veldig fort» bekreftet en kilde ved Helsedirektoratet. ${ }^{23} \mathrm{~A}$ contrario argumenterte Helse Bergen «at prosjektet burde ha vært kontinuert i minst ett til to år, men da med en langt lavere innsats» (Rapport fra Helse Bergen 2015: 21). Organisasjonen forfektet en slik tilnærming av to hovedgrunner: først og fremst fordi utbruddsepidemiologien fortsatt var usikker og antall saker kunne øke igjen; men også fordi det lokale helsesystemet, som hadde blitt redusert av epidemien, trengte støtte på lengre sikt (Helse Bergen 2015: 6; 21). Ulike intensjoner og derfor ulike posisjoner på securitization-kontinuumet forklarer konflikten mellom de to institusjonene. Som en byråkrat ved Helsedepartementet sa: «de hadde et annet formål med oppdraget». ${ }^{24}$ Helse Bergen som jobbet direkte med de frivillige ble styrt i

\footnotetext{
${ }^{21}$ Intervju, ansatt ved det norske Helsedirektoratet, 10. november 2016

${ }^{22}$ Intervju, ansatt ved Direktoratet for samfunnssikkerhet og beredskap, 26. oktober 2016, kursiv lagt til.

${ }^{23}$ Intervju, ansatt ved det norske Helsedirektoratet, 29. september 2016.

${ }^{24}$ Intervju, ansatt ved det norske Helsedirektoratet, 29. september 2016.
} 
hovedsak av «internasjonal solidaritet» som de stadfestet i egen rapport (Helse Bergen 2015: 62). De avviste derfor regjeringens delvise securitization av responsen og anså det som et svik overfor det altruistiske ved dette prosjektet - en reaksjon som er å forvente gitt idealet om renhet som finnes i humanitær handling (Thieren 2007; Calhoun 2013: 52). En kilde ved Helse Bergen fortalte meg for eksempel:

Helsedirektoratet anbefalte departementet å stoppe prosjektet så fort som mulig. Da trusselen mot norske statsborgere, mot den vestlige delen av Europa [...] var over så stoppet de bare prosjektet med en gang! Jeg var veldig skuffet over det! [...] Da vi innså hvordan dette prosjektet ble avsluttet følte jeg en slags skam fordi fokuset på internasjonal solidaritet og altruisme ble tatt vekk fra oss - det er jeg veldig skuffet over! ${ }^{25}$

Det faktum at ulike aktører har ulike oppfatninger om hvorvidt en respons burde bli ansett som en eksistensiell trussel eller ikke antyder en "delvis securitization» av ebolakrisen. I tillegg ser det ut til at balansen ble flyttet til fordel for sikkerhetsinteresser etter som krisen utviklet seg, selv om det humanitære aspektet ved responsen vedvarte gjennom hele perioden. Denne forflytningen skapte ergrelse og en følelse av bedrageri blant noen av aktørene som var direkte involvert, men interessant nok ser det ut til at den offentlige meningen ble lite påvirket siden dette ikke ble debattert i nasjonale media.

\section{En universalistisk forståelse av globalhelsesikkerhet?}

Blandingen av elementer fra både idealpolitikk (humanitær motivasjon) og realpolitikk (sikkerhetsinteresser) i den norske ebolaresponsen gjør det vanskelig å relatere saken til enten en "statist》- eller "globalist》-tilnærming til global helsesikkerhet. Politikkens altruistiske tolkningsramme, dets legitimering av tiltak som en moralsk forpliktelse om å bidra med støtte og dets humanitære målsetning impliserer en "globalist»tilnærming til ebolakrisen. Regjeringens sikkerhetsinteresser, deres mål om å beskytte Norge ved å anta en proaktiv politikk for å begrense virusets spredning og deres investering i forskning for medisinske mottiltak (en vaksine) korresponderer imidlertid med et «statist»-perspektiv på verdier og interesser (Roemer-Mahler \& Elbe 2016). Jeg foreslår derfor at den norske ebolaresponsen ligger i gråsonen mellom «statist»- og «globalist»-perspektiver, et tredje perspektiv jeg kaller en «universalistisk» tilnærming til global helsesikkerhet. Det samsvarer med en innsats for å forsone formål som er altruistiske og de som er drevet av egeninteresse: prioriteringene til både utviklede land og utviklingsland; sikkerheten til stater og individer, og av dermed, den globale verden.

Dette er ikke nye interesser for Norge. Oppropet The Oslo Ministerial Declaration (2007), igangsatt av Frankrike og Norge med støtte fra utviklingsland, representerer et tidlig forsøk på et balansert kompromiss mellom ulike utfordringer, interesser og prioriteringer (Davies 2010b: 1187; Møgedal \& Alveberg 2010). Dette

\footnotetext{
${ }^{25}$ Intervju, ansatt ved Helse Bergen 22. desember 2016.
} 
oppropet om å gjøre global helse til et utenrikspolitisk tema adresserte interesser fra «statist»-tilnærmingen til global helsesikkerhet (smittsomme sykdommer med pandemisk potensiale), i tillegg til «globalist»-perspektiver (miljøutfordringer, utviklingsproblematikk, handelspolitikk). Den underliggende drivkraften var at problemer for de mest sårbare kan bli trusler for oss alle og at forbedring av helse et sted i verden på denne måten kan ha positive ringvirkninger for resten av verden (Davies 2010a: 145). I debatten som fulgte ebolakrisen erklærte den norske statsministeren Solberg at «å beskytte de sårbare er å beskytte oss selv» (Statsminister Erna Solberg, sitert i: CEPI 2017, oversatt her til norsk) - det samme argumentet som ble forfektet for ti år siden. Denne «universalistiske» tilnærmingen til global helsesikkerhet springer ut av det økonomiske begrepet for globale kollektive goder, hvori helsesikkerhet er ansett som et gode alle drar nytte av (ikke-ekskluderbart) hvis forbedring er fordelaktig for alle (ikke-rivaliserende) (Ooms et al. 2017). En slik måte å tenke på åpner opp for muligheter for kollektiv handling basert på samarbeid mellom utviklingsland og utviklede land, fordi, tross alt, «finnes det ikke noe urettferdig i å søke å begrense spredningen av smittsomme sykdommer» (Davies, Kamradt-Scott \& Rushton 2015: 135). Et slikt perspektiv åpner også opp for en mer nyansert analyse av handlinger utført med tanke på global helsesikkerhet som ofte er hverken fullstendig sikkerhetsdrevet eller fullstendig altruistiske.

\section{Konklusjon}

Den norske regjeringens respons på ebolakrisen var i hovedsak påvirket av hjemkomsten av en ebolasmittet helsearbeider (kontekst), som fremskyndte anerkjennelsen av utbruddet som en «krise» og utløste en sterk offentlig reaksjon. Denne hendelsen genererte en overflod av solidaritet og godvilje som presset regjeringen til å planlegge et humanitært tiltak som oppfylte en moralsk forpliktelse om å hjelpe (norm). Interessant nok fremhevet det også sikkerhetsinteresser blant nasjonale helsemyndigheter som søkte en måte å begrense epidemiens spredning og å håndtere økende frykt blant befolkningen (interesse). I møte med konteksten, normene og interessene som formet denne politikken (Wendt 1999: 139) argumenterer jeg at den norske regjeringen delvis presenterte sin respons på ebola som et eksistensielt sikkerhetsproblem, noe som åpnet opp for å mobilisere eksepsjonelle ressurser. Denne strategien møtte imidlertid motstand, spesielt fra frivillige som uttrykte frustrasjon over forventninger som ikke hadde blitt oppfylt hva gjaldt responsens utføring, hvilket indikerer at responsen ble kun delvis securitized. Min analyse av den norske ebolaresponsen er i overenstemmelse med flere studier som påpeker den viktige rollen sikkerhetsinteresser spiller i global respons på ebola. Samtidig nyanserer jeg dette ved å understreke også andre motiver, som for eksempel et genuint ønske om å vise solidaritet med rammede land og å gi dem velment bistand. Jeg argumenterer for at det teoretiske skillet mellom en «statist»og en "globalist»-tilnærming til global helsesikkerhet ikke yter rettferdighet overfor den norske regjeringens komplekse mål og verdier som i sin tur drev regjeringens respons 
på ebola. Jeg foreslår derfor et tredje perspektiv, en «universalistisk» forståelse av global helsesikkerhet som tar det globale som referansepunkt for sikkerhet og som åpner opp for et kompromiss mellom idealpolitikk og realpolitikk. Selv om en slik universalistisk tilnærming kan være et nyttig analytisk verktøy hviler det imidlertid på en sårbar balanse mellom tidvis motsatte verdier og formål og det er derfor vanskelig å operasjonalisere. En ekspert på norsk global helsepolitikk, sterkt drevet av humanitære idealer og veldig skeptisk til USAs forståelse av global helsesikkerhet - som er arketypen på «statist»-tilnærmingen - kom med denne advarselen:

Hele begrepet [om global helsesikkerhet] er risikabelt og vi må vite nøyaktig hva vi driver med [...] Man burde ikke følge storebror [USA] i alt! ${ }^{26}$

\section{Om artikkelen}

Artikkelen er basert på forfatterens masteroppgave i Culture, Environment and Sustainability ved Senter for utvikling og miljø (SUM). Den ble opprinnelig skrevet på engelsk og oversatt til norsk med god hjelp av Hedda Moland og støtte fra Senter for utvikling og miljø. Jeg ønsker å takke min veileder Sidsel Roalkvam, samt Katerini Storeng, Sonja Kittelsen, Ann Louise Lie, Maren Kloster, Hanneke Pot og Seydou Drabo for mange gode innspill.

\section{Referanser}

Adams, Vincanne, Novotny, Thomas \& Leslie, Hannah (2008) «Global health diplomacy» Medical Anthropology, 27 (4): 315-323.

Aldis, William (2008) «Health security as a public health concept: a critical analysis» Health Policy and Planning, 23 (6): 369-375.

Balzacq, Thierry (2005) «The three faces of securitization: Political agency, audience and context» European fournal of International Relations, 11 (2): 171-201.

Brown, Garrett Wallace, \& Stovea, Preslava (2014) «Reevaluating health security from a cosmopolitan perspective» i Simon Rushton \& Jeremy Youde (red.), Routledge Handbook of Global Health Security. London \& New York: Routledge (304-317).

Brysk, Alison (2009) Global Good Samaritans: Human Rights as Foreign Policy: Oxford: Oxford University Press.

Calhoun, Craig (2013) «The idea of emergency: humanitarian action and global (dis)order» i Didier Fassin \& Mariella Pandolfi (red.), Contemporary States of Emergency: The Politics of Military and Humanitarian Interventions Zone Books (29-58).

CDC (2014) "Questions and Answers: Estimating the Future Number of Cases in the Ebola Epidemic in Liberia and Sierra Leone, 2014-2015» [Pressemelding]. Tilgjengelig på http:/www.cdc.gov/vhf/ebola/ outbreaks/2014-west-africa/qa-mmwr-estimating-future-cases.html

CEPI. (2017) «Global partnership launched to prevent epidemics with new vaccines» [Pressemelding]. Tilgjengelig på http://cepi.net/cepi-officially-launched

Dahl, Ann-Sofie (2005) «Sweden, once a moral superpower, always a moral superpower?» International fournal, 61 (4): 895-908.

Davies, Sara E. (2008) «Securitizing infectious disease» International Affairs, 84 (2): 295-313.

Davies, Sara. E. (2010a) Global politics of health Cambridge, England: Polity Press.

Davies, Sara. E. (2010b) «What contribution can International Relations make to the evolving global health agenda?" International Affairs, 86 (5): 1167-1190.

Davies, Sara. E., Kamradt-Scott, Adam \& Rushton, Simon (2015) Disease diplomacy: international norms and global health security: Johns Hopkins University Press.

\footnotetext{
${ }^{26}$ Intervju med ekspert på norsk global helsepolitikk, 15. september 2016.
} 
de Bengy Puyvallee, Antoine, \& Kittelsen, Sonja (Forthcoming) "'Disease knows no borders”: Pandemics and the politics of global health security» i Kristian. Bjørkdahl \& Benedicte Carlsen (red.), Pandemic, Publics and Politics: Pilgrave Pivot.

De Carvalho, Benjamin, \& Sande Lie, Jon Harald (2015) «A great power performance: Norway, status and the policy of involvement» i Benjamin De Carvalho \& Ivar B. Neumann (red.), Small states and status seeking: Norway's quest for international standing Routledge (56-72).

Elbe, Stefan (2010) Security and global health: Polity. Cambridge \& Malden.

Hansen, Lene (2011) "Theorizing the image for security studies: visual securitization and the Muhammad Cartoon Crisis» European fournal of International Relations, 17 (1): 51-74.

Helsedirektoratet (2015a) Erfaringsgjennomgang av norsk ebolahåndtering. Tilgjengelig på https://goo.gl/rWLns2.

Helsedirektoratet (2015b) «Hjelper alle, redder mange» [Pressemelding]. Tilgjengelig på https://helsedirektoratet.no/nyheter/hjelper-alle-redder-mange

Helsedirektoratet (2016) Norwegian Emergency Medical Teams. Utredning av tverrsektoriell beredskapsordning for akutte kriser

Helse Bergen. (2015) Sluttrapport. Oppdrag til Helse Vest RHF om mobilisering av norsk helsepersonell for humitcer bistand $i$ Sierra Leone Tilgjengelig på https://goo.gl/OXoWhs

Honigsbaum, Mark (2017) «Between Securitisation and Neglect: Managing Ebola at the Borders of Global Health" Medical History, 61 (2): 270-294.

Huang, Yanzhong (2014) «The Downside of Securitizing the Ebola Virus» Global Health Program. Tilgjengelig på https://www.cfr.org/expert-brief/downside-securitizing-ebola-virus

Kamradt-Scott, Adam (2016) «WHO's to blame? The World Health Organization and the 2014 Ebola outbreak in West Africa" Third World Quarterly, 37 (3): 401-418.

Kamradt-Scott, Adam, Harman, Sophie, Wenham, Claire, \& Smith, Frank (2015) «Saving Lives: The civilmilitary response to the 2014 Ebola outbreak in West Africa». The University of Sidney. Tilgjengelig på https://sydney.edu.au/arts/ciss/downloads/SavingLivesPDF.pdf

Lakoff, Andrew (2008) «From Population to Vital System: National security and the changing object of public health" i Andrew Lakoff \& SStephen Collier (Red.), Biosecurity Interventions. New York: Columbia University Press (33-60).

Lakoff, Andrew (2017) Unprepared. Global Health in a time of emergency. University of California Press.

Lamont, Christopher (2015) Research Methods in International Relations. Sage.

Lancaster, Carol (2007) Foreign Aid. Diplomacy, Development, Domestic Policy. Chicago \& London: The University of Chicago Press.

Leira, Halvard et al (2007) «Norske selvbilder og norsk utenrikspolitikk» Norsk utenrikspolitisk institutt, april 2007:1-46.

McDonald, Matt (2008) «Securitization and the construction of security» European fournal of International Relations, 14 (563): 563-587.

McInnes, Colin (2014) "The Many meanings of health security» i Simon Rushton \& Jeremy Youde (red.), Routledge handbook of global health security. London og New York: Routledge (7-17).

McInnes, Colin (2016) «Crisis! What crisis? Global health and the 2014-15 West African Ebola outbreak». Third World Quarterly, 37 (3): 380-400.

McInnes, Colin \& Lee, Kelley (2006) «Health, security and foreign policy» Review of International Studies, 32 (1): 5-23.

McInnes, Colin \& Lee, Kelley (2012) Global Health and International Relations: Polity Press.

McInnes, Colin \& Rushton, Simon (2010) «HIV, AIDS and security: where are we now?» International Affairs, 86 (1): 225-245.

McInnes, C., \& Rushton, Simon (2011) «HIV/AIDS and securitization theory» European fournal of International Relations, 19 (1): 115-138.

Møgedal, Sigrun, \& Alveberg, Benedikte Louise (2010) «Can Foreign Policy Make a Difference to Health?» PLOS Medicine, 7 (5).

NORAD (2010) Norwegian humanitarian response to natural disasters. Case of Haiti Earthquake fanuray 2010. Tilgjengelig på https://goo.gl/OhCjrN.

Nunes, Joao (2014) «Questioning health security: Insecurity and domination in world politics» Review of International Studies, 40 (5): 939-960.

Nunes, Joao (2016) «Ebola and the production of neglect in global health» Third World Quarterly, 37 (3): 542-556.

Ooms, Gorik, Claudia Beiersmann, Walter Flores, Johanna Hanefeld, Olaf Müller, Moses Mulumba, Trygve Ottersen, Malabika Sarker, og Albrecht Jahn (2017) «Synergies and tensions between universal health 


\section{Antoine de Bengy Puyvallée}

coverage and global health security: why we need a second 'Maximizing Positive Synergies' initiative" BMF Global Health, 2.

Pallister-Wilkins, Polly (2016) «Personal Protective Equipment in the humanitarian governance of Ebola: between individual patient care and global biosecurity" Third World Quarterly, 37(3), 507-523.

Reus-Smit, Christian (1999) The moral purpose of the state: culture, social identity, and institutional rationality in international relations. Princeton, N.J: Princeton University Press.

Roalkvam, Sidsel, \& Jani, Jagrati (2013) "Rights and obligations in national health governance» i Sidsel Roalkvam, Desmond McNeill, \& Stuart Blume (Red.), Protecting the World's Children: Immunisation policies and Practices Oxford (115-147).

Roemer-Mahler, Anne, \& Elbe, Stefan (2016) «The race for Ebola drugs: pharmaceuticals, security and global health governance» Third World Quarterly, 37 (3): 487-506.

Roemer-Mahler, Anne \& Rushton, Simon (2016) «Introduction: Ebola and International Relations» Third World Quarterly, 37 (3): 373-379.

Rosenberg, Charles (1989) "What is an epidemic? AIDS in historical perspective» Daedalus, 118 (2): 1-17

Rushton, Simon (2011) «Global Health Security: Security for Whom? Security from What?» Political Studies, 59 (4): 779-796.

Rushton, Simon, \& Youde, Jeremy (2015) Routledge handbook of global health security: Routledge/Taylor \& Francis Group.

Stokke, Olav (1989) Western middle powers and global poverty : the determinants of the aid policies of Canada, Denmark, the Netherlands, Norway and Sweden (Vol. 64). Uppsala: The Scandinavian Institute of African Studies in cooperation with The Norwegian Institute of International Affairs.

Stortinget. (2014) Sak nr. 4: Redegjørelse av utenriksministeren og helse- og omsorgsministeren om smitteutbruddet av ebola $i$ Vest-Afrika. Tilgjengelig på https://goo.gl/MqvADk.

Thieren, Michel (2007) «Health and foreign policy in question: the case of humanitarian action» World Health Organization. Bulletin of the World Health Organization, 85 (3): 218-224.

Tvedt, Terje (2007) «International Development Aid and Its Impact on a Donor Country: A Case Study of Norway» The European Fournal of Development Research, 19 (4): 614.

UD (2014a) «Norge bidrar til å stanse Ebola-utbruddet i Guinea» [Pressemelding]. Tilgjengelig på https://www. regjeringen.no/no/aktuelt/ebola-utbrudd/id755278/

UD (2014b) «Norway doubles support for fight against Ebola» [Pressemelding]. Tilgjengelig på https://www. regjeringen.no/en/aktuelt/fight_ebola/id2005373/

UD (2014c) «Norway increases funding to combat the Ebola outbreak in West Africa» [Pressmelding]. Tilgjengelig på https://www.regjeringen.no/en/aktuelt/Norway-increases-funding-to-combat-the-Ebola-outbreakin-West-Africa-/id765521/

UD (2014d) «Norway pledges NOK 70 million to new World Bank fund to fight Ebola» [Pressemelding]. Tilgjengelig på https:/www.regjeringen.no/en/aktuelt/fund_ebola/id2005813/

UD (2014e) «Norway trebles funding to combat Ebola» [Pressemelding]. Tilgjengelig på https://www. regjeringen.no/en/aktuelt/ebola_fundings/id2000878/

UD (2014f) «Norwegian Foreign Minister in Liberia: Norway pledges a further NOK 75 million to the fight against Ebola» [Pressemelding]. Tilgjengelig på https://goo.g1/N5JrfQ

UD (2015a) «Norway adjusts its Ebola response» [Pressemelding]. Tilgjengelig på https://www.regjeringen.no/ en/aktuelt/ebola-response/id2403173/

UD (2015b) «Norway increases humanitarian support to Nepal» [Pressemelding]. Tilgjengelig på https://www. regjeringen.no/en/aktuelt/nepal_support/id2425035/

UNSC (2014) Resolution 2177, adopted by the Security Council at its 7268th meeting, on 18 September 2014. Tilgjengelig på http://www.ifrc.org/docs/IDRL/UN\%20SC\%20Res.pdf

Weir, Lorna (2014) «Inventing global health security, 1994-2005» i Simon Rushton \& Jeremy Youde (red.), Routledge handbook of global health security London \& New York: Routledge (18-31).

Wendt, Alexander (1999) Social Theory of International Politics: Cambridge University Press.

WHO (2016a) «Ebola data and statistics» Tilgjengelig på http://apps.who.int/gho/data/view.ebola-sitrep. ebola-summary-20160511 ?lang=en

WHO (2016b) «Ebola Response Funding - Donor contribution to WHO's Ebola response as of April 2016» [Pressemelding]. Tilgjengelig på http://www.who.int/csr/disease/ebola/funding/en/ 


\title{
Norway's Response to Ebola: Balancing Altruistic and Security Concerns ${ }^{1}$
}

\author{
Antoine de Bengy Puyvallée \\ Centre for Development and the Environment, University of Oslo
}

\begin{abstract}
This article explores the motivations behind Norway's contributions to the global response to Ebola (2014). Unpacking the interests, norms and context at play, it finds that the repatriation of an Ebola-infected volunteer triggered a strong governmental response. Humanitarian in nature but partially securitized, this response was driven by altruistic and security concerns: a desire to provide assistance and the ambition to contain the epidemic at its source, while managing domestic fears. This analysis concurs with publications highlighting the centrality of security considerations in the global Ebola response, while suggesting that humanitarian motivations should not be overlooked. Finally, it argues that the theoretical divide between a "statist" and "globalist" approach to global health security does not fully capture the complexity at play in the operationalisation of the concept. Therefore, the analysis introduces the idea of a "universalist" understanding of global health security, using the global level as referent for security and allowing for a balance between realpolitik and idealpolitik.
\end{abstract}

Keywords: Ebola - global health security - securitization • humanitarian $\cdot$ constructivism

\section{Introduction}

Medical anthropologist Charles Rosenberg suggests that epidemics are a dramaturgic event that take place in three acts: communities usually start with a period of "denial", before the situation reaches the point that it can no longer be ignored. The urgency is then "recognized" by the authorities who provide an explanation to the problem (frame it), and ultimately, set-up a public response (Rosenberg 1989: 3-9). The Norwegian government's response to the Ebola epidemic that ravaged Sierra

${ }^{1}$ This article received the 'Ordingpris' for 2017, the journal's annual prize for best scholarly article written by an undergraduate or graduate student from one of the Nordic countries. 
Leone, Liberia and Guinea in 2014-2015 suggests a similar dramaturgy, with an extremely rapid transition in October 2014 from "recognition" to "response set-up". The Ministry of Foreign Affairs' first press release on Ebola was published in April 2014 and took a neutral and descriptive tone, expressing support for the work of the medical humanitarian non-governmental organization (NGO) Doctors Without Borders (MSF) (MFA 2014a). By late July 2014, the situation in West Africa was described as one of "great concern", but the public was reassured that "the number of cases reported in Guinea is dropping” (MFA 2014c). By early autumn that year, the sense of urgency was mounting; in mid-September, the situation was described as "dramatic" (MFA 2014e); and by 6 October 2014, as "critical” (MFA 2014b). Four days later, 10 October 2104, the Ministry of Foreign Affairs used the word "crisis" for the first time (MFA 2014d).

The infection of a female Norwegian MSF staff member (a medical doctor) in Sierra Leone played a critical role in precipitating the recognition of a "crisis" and the set-up of a public response. Diagnosed with Ebola on 5 October, her repatriation to Norway three days later gained huge media attention. Spectacular pictures of her admission to Oslo's main hospital in a confinement bed and escorted by health personnel in full protective equipment made news headlines for several days, stirring frenetic government communication (three press releases in only 10 days) (MFA 2014b, 2014d, 2014f). Ebola had made its way to Norway, making it no longer possible to tone down the crisis. The day following her return, the government announced its decision to send public health personnel to a field hospital in Moyamba, Sierra Leone, as part of an operation led by the United Kingdom (Health-Directorate 2015a: 5). Within a week, the government quadrupled its contributions to international efforts to fight Ebola, from NOK 77.7 million to NOK 329 million (MFA 2014b, 2014d, 2014f). Further contributions raised the budget allocated to the Ebola crisis to NOK 500 million (MFA 2015a). Table 1 provides an overview of the pledges announced by the Norwegian Ministry of Foreign Affairs (MFA) through its press releases. Put in perspective, the budget allocated to fight Ebola internationally was massive, more than twice as large as that of the Norwegian humanitarian responses after the earthquakes in Nepal (2015, NOK 230 million) (MFA 2015b) and in Haiti (2010, NOK 200 million) (NORAD 2010).

In this article, I seek to understand what motivated the deployment of these enormous resources to combat Ebola internationally. To do so, I analyze the Norwegian government's understanding of the policy problem (the Ebola crisis), explore the agenda and goals that led to the set-up of a public response and contrast these motivations with the values put forward to legitimize the intervention. I argue that the repatriation of a sick health worker precipitated a shift from understanding Ebola essentially as a humanitarian problem to understanding it as a security threat, justifying the mobilization of exceptional resources (Lakoff 2017: 149; McInnes 2016: 381). 
Norway's response to Ebola: balancing altruistic and security concerns

Table 1. Financial contribution to fight Ebola announced by the MFA in its press releases

\begin{tabular}{lllllllll}
\hline & $\begin{array}{l}\text { 3. } \\
\text { April } \\
\text { 2014. }\end{array}$ & $\begin{array}{l}\text { July } \\
\mathbf{2 0 1 4}\end{array}$ & $\begin{array}{l}\text { September } \\
\mathbf{2 0 1 4}\end{array}$ & $\begin{array}{l}\text { 6. } \\
\text { October } \\
\mathbf{2 0 1 4}\end{array}$ & $\begin{array}{l}\text { October } \\
\mathbf{2 0 1 4}\end{array}$ & $\begin{array}{l}\text { 14. } \\
\text { October } \\
\mathbf{2 0 1 4}\end{array}$ & $\begin{array}{l}\mathbf{5 .} \\
\text { December } \\
\mathbf{2 0 1 4}\end{array}$ & $\begin{array}{l}\text { March } \\
\mathbf{2 0 1 5}\end{array}$ \\
\hline $\begin{array}{l}\text { Additional contribution } \\
\text { announced } \\
\text { (million NOK) }\end{array}$ & 4 & 15 & 58.7 & 106.3 & 70 & 75 & $\star$ & $\star \star$ \\
$\begin{array}{l}\text { Total amount pledged } \\
\text { (million NOK) }\end{array}$ & 4 & 19 & 77.7 & 184 & 254 & 329 & 334 & 500 \\
\hline
\end{tabular}

* The press release from December $5^{\text {th }}$ details the plans for a vaccination trial project, and recapitulates the budget allocated to the Ebola crisis.

${ }^{\star \star}$ The last press release of March 2015 broadly summarizes Norway's main financial contributions to fight Ebola.

\section{Theoretical background}

The last decade, a few scholars of International Relations have critically engaged with the concept of global health security (Davies 2008, 2010b; Davies, Kamradt-Scott, and Rushton 2015; Elbe 2010; McInnes 2014; Rushton 2011; Rushton and Youde 2015). Rooted in securitization theory and social constructivism (McInnes and Lee 2006, 2012; McInnes and Rushton 2011), their approach aims to understand how and why global health (or outbreak events) are perceived and framed as security issues, and analyze what consequences the securitization (i.e. the framing of epidemics as existential security threats) of global health entails (McInnes and Rushton 2010). To operationalize this research agenda, it is necessary to unpack the values, interests, agendas, and power-relations that underpin the definition of health threats and the set-up of responses to address them (McInnes and Lee 2012: 4-5; Davies, Kamradt-Scott, and Rushton 2015: 10-11). This is what I do in the context of the Norwegian response to Ebola.

Within the literature on global health security, scholars tend to introduce an irreconcilable dichotomy regarding actors' motivations for engaging with health security, they are driven either by security objectives (realpolitik), or by development and humanitarian concerns (idealpolitik) - but not both at the same time. Sara Davies, for instance, distinguishes between a "statist" (taking the state as referent for security) and a "globalist" (taking the individual as referent for security) approach to global health security, although she recognizes that the two approaches can converge in a few cases (Davies 2008). On the one hand, most studies analyzing the "statist" operationalization of health security have concluded that donor countries' security concerns (realpolitik) prevail (Brown and Stovea 2014: 305; Lakoff 2008: 59; Rushton 2011: 780; Davies 2010b: 1177; Aldis 2008: 373). This implies that projects aiming to improve global health security are often implemented based on foreign policy principles, reflecting national interests - rather than ideas of solidarity 
(Thieren 2007: 219). Therefore, many worry that prioritizing health security measures leads to a reallocation of resources away from developing countries' main interests, i.e. issues that are already (and not potentially) having disastrous health effects (Rushton 2011). In Davies' words, actions to counter global health threats "could quickly become mired in self-interest" as "assistance should be provided to developing states to help "fix" their health infrastructure because it protects the West and states that are currently "secure" from these pathogens in the long run" (Davies 2010b: 1177). On the other hand, the "globalist" approach to global health security derives from critical security studies and attempts to shift the referent of security from the state to the individual. It is rooted in cosmopolitan ideas of development, global justice and solidarity and privileges an "ethos of care" over an "ethos of security” (Brown and Stovea 2014: 304; see also: Adams, Novotny, and Leslie 2008: 304). As such, health security is seen as a key feature of human security, as well as an instrument to address other insecurities for the individual (Elbe 2010: 108).

The Ebola epidemic of 2014-2015 that infected over 28,000 people and killed more than 11,000 (WHO 2016a) has been analyzed as a global crisis because of its framing as a security threat after the repatriation of infected health workers and the subsequent spreading of the virus worldwide (McInnes 2016; Lakoff 2017: 151). Following the return of sick doctors and nurses to the US, the United Nations Security Council adopted a resolution qualifying Ebola as a "threat to international peace and security" (UNSC 2014). The resolution's main objective was to highlight the security risks emerging from the Ebola crisis to mobilize the global community, coordinate efforts, and foster collective action to contain the epidemic (McInnes and Rushton 2011). Analyses suggest that a "statist" approach to global health security dominated during the Ebola crisis, i.e. the global response was dominated by western countries' security concerns (Roemer-Mahler and Rushton 2016). The securitization of the crisis raised serious ethical problems, such as the mobilization of considerable financial resources on the short term to contain the epidemic - at the expense of longer-term objectives such as health systems recovery - (Huang 2014), the involvement of the military (McInnes 2016; Kamradt-Scott et al. 2015) and the rush to test experimental treatments and vaccines (Roemer-Mahler and Elbe 2016). It also diverted attention from a fair allocation of blame and responsibilities (Honigsbaum 2017; Kamradt-Scott 2016).

In this paper, I argue that if security concerns raised by the repatriation of a health worker indeed came to dominate the Norwegian response to Ebola, this should not override critical humanitarian aspirations. More generally, I suggest that the analysis of the global response to Ebola has tended to be reduced to state interests, powerrelations, or the consequences of the securitization of the crisis, and has largely omitted the role of national identity and values in the formation of as per proposed in the comment above foreign policy (Reus-Smit 1999). Alexander Wendt (1999: 139) recalls that foreign policy is elaborated by taking into account interests, but also a context (material conditions, for instance the repatriation of a health worker), and norms 
(deriving from ideas and identity, for instance the framing and role of humanitarian aid). By providing the first account of the motivations that drove a donor country's response to Ebola, I aim to take into account the complexity of all these factors. Norway represents an interesting case to study for two reasons. The first is that Norway was an influential player during the Ebola crisis, contributing, for instance, to the WHO's Ebola response at a similar level to the UK and Germany). ${ }^{2}$ The second is that Norway is often portrayed a "humanitarian great power" (De Carvalho and Sande Lie 2015: 60); the country has traditionally framed humanitarian aid as an altruistic gesture and a key component of its foreign policy (Stokke 1989: 172; Leira 2007). Norway is therefore likely to challenge the idea that the response to the Ebola crisis was security-driven. Finally, I conclude the paper with a theoretical proposal arguing that distinguishing between "statist" and "globalist" perspectives on global health security does not reflect the complexity of motivations that drove Norway's response. I propose therefore to develop a third analytical category that I coin "universalist", taking the global level as a referent for security, and allowing for an understanding of global health security as both a security and humanitarian policy issue.

\section{Methods}

This article draws on an in-depth analysis of relevant official policy documents, a review of the literature and 18 semi-structured interviews, led from April to December 2016. I conducted 13 interviews with bureaucrats from Ministries and Directorates involved in the set-up of the response, two with doctors from the Bergen Health Trust that participated in the response, and three with Norwegian global health and foreign policy experts. I compared the results obtained by each method to ensure reliable and valid results (triangulation) (Lamont 2015: 79). Given the sensitivity of the topic discussed and the small size of the community of actors involved, I decided to anonymize the data collected from interviews, indicating only the informant's institution of origin.

\section{Ebola, a race against time to save lives and a ticking bomb for Norway's security and the legitimacy of the government}

21 October 2014. Two weeks after her return to Norway, the volunteer infected by Ebola was safe and discharged from the hospital. She pronounced a few words during a press conference, repeated later by the Minister of Health in his address to the Parliament: "The clock is ticking; the number of deaths is rising. We have to act now". ${ }^{3}$ I will show in the following that even though the government did perceive the

${ }^{2}$ Data aggregated by the author from WHO's official statistics (WHO 2016b).

${ }^{3}$ Bent Høie in Stortinget (2014: 370, translated from Norwegian by the author). 
situation as a humanitarian crisis, it also considered Ebola a ticking bomb, potentially threatening Norway's security and its own legitimacy.

\section{"A moral obligation to help": Norway, a do-gooder}

Norwegians have traditionally framed humanitarian and development aid as a moral obligation to help. In his study on the origins of Norwegian aid policy, Olav Stokke concluded that core values and norms of Norwegian society are mobilized to frame aid as altruistic policy. These include the belief in the virtues of the welfare state (presupposing a large, powerful and interventionist state), the Christian philosophy of universal brotherhood (leading to a moral obligation to be part of international solidarity), and staunch support for human rights (Stokke 1989: 172). More recently, Terje Tvedt called Norwegian aid policy the result of a "regime of goodness" or a "dogooder regime", which was "organized around and sought legitimacy from the founding dictum - it is morally correct for people who are well-off to give something of their wealth to people who have very little" (Tvedt 2007: 621). This framing led Norwegians to display a high level of support for humanitarian aid, consensually seen as a "direct expression of moral virtue" (Leira 2007: 10) and assosciate it thus with an ideal of purity. In the words of an expert on Norwegian development policy, "We [Norwegians] have this image of ourselves as being the saviours in a way - the do-gooders. That's very much a narrative when it comes to Norwegian interventions abroad, especially if it's financed by the development aid budget" . This has also shaped the country's reputation abroad, qualified - often together with the Nordic countries - as "good power" (De Carvalho and Sande Lie 2015: 56), "moral superpowers" (Dahl 2005: 895), "global good Samaritans" (Brysk 2009), or "humane internationalists" (Lancaster 2007: 190).

In line with this tradition, the Norwegian government framed the Ebola epidemic primarily as a humanitarian crisis, to which the country had a moral obligation to respond. "Norway and other resourceful countries must contribute to scaling up assistance", 5 declared, for instance, the Minister of Health to Parliament when introducing the Norwegian contribution to global efforts to fight Ebola. Several of my informants confirmed that the desire to do good was a central driver of the government's response. "I think it's quite deep in our souls that we should try to contribute. Not to get anything back, but as a rich country, we see it as part of our culture to contribute what we can"6, a senior bureaucrat from the Directorate of Health told me, whilst an advisor at the Ministry of Health recalled that "There was this naive thinking that this could help at a sort of high level, making the world a better place. I think it's the way many people think, also in government institutions". ${ }^{7}$ The return of the sick health worker and her message of solidarity delivered the day of her

\footnotetext{
${ }^{4}$ Interview with an expert of Norwegian development policy, 3 November 2016.

${ }^{5}$ Bent Høie in the Stortinget (2014: 370, translated from Norwegian by the author, emphasis added). ${ }^{6}$ Interview, staff member of the Norwegian Directorate of Health, 29 September 2016.

${ }^{7}$ Interview, staff member of the Norwegian Ministry of Health, 30 October 2016.
} 
discharge brought light to the humanitarian situation in West Africa and provoked a desire to "do something" in public opinion, recalled a source from the Ministry of Health. ${ }^{8}$ These expectations created pressure on the public authorities to fulfil the country's moral duty by setting up a humanitarian response. The government tried to address public concerns by focusing its communication on the humanitarian aspects of the response. The Directorate of Health's press release presenting Norway's main contribution to the international efforts against Ebola (setting up a field hospital in Sierra Leone) strategically focused on the volunteers, using them as a vehicle to project values of selflessness, solidarity and sacrifice (Health-Directorate 2015b). What was highlighted was not so much the project's content and objectives, but its altruistic intentions, illustrated by the health workers' personal stories. This framing resonated strongly with the Norwegian identity and was instrumental in legitimizing the response, as suggested by an informant from the Ministry of Health: "Having the feeling that you are contributing, I think, is important. That's what the media sold and that's fair enough!"9

\section{The government's security intentions: protecting Norway and managing the} population's angst

The infected volunteer's repatriation not only sparked an outpouring of solidarity and goodwill, it also gave credibility to the risk of an uncontrolled spread of the epidemic to Norway. Considering Ebola as a threat to the country, the government intended with its response to fulfil a moral duty to help, but also to protect its population by contributing to international efforts to contain the epidemic. In addition, health authorities were able to show themselves as being on top of the situation, to legitimate themselves and to manage the population's fear.

\section{Ebola, a security threat to be contained at its source}

The infected health worker's return, combined with worrisome epidemiological predictions (the US Centre for Disease Control forecasted between 500,000 and 1.4 million cases three months later (CDC 2014)) raised great concern amongst health authorities - as recalled by a senior bureaucrat from the Directorate of Health:

We had the last pandemic in mind - the H1N1 outbreak - it was not long ago! It hit Norway at some point rather hard. We know that we'll get something serious some time. A lot of us were thinking: "Is this what's starting now?" We were very anxious early on that autumn. ${ }^{10}$

The perception of an imminent threat was constantly justified in my interviews by the same argument: by expanding the interconnection of the world, globalization

\footnotetext{
${ }^{8}$ Interview, staff member of the Norwegian Ministry of Health, 30 October 2016.

${ }^{9}$ Interview, staff member of the Norwegian Ministry of Health, 30 October 2016.

${ }^{10}$ Interview, staff member of the Norwegian Directorate of Health, 10 November 2016.
} 
increases our vulnerability to infectious diseases. Bureaucrats from different ministries and directorates involved in the response set-up told me, for instance, "We think that it is a fact that $[\ldots]$ the world is shrinking rapidly, and therefore, a disease in another part of the world may become a problem at home"11, "Infections do not see borders"; 12 "Epidemics spread over borders, [...] you don't know when they will arrive in Norway!" 13 and that "After all, a disease sees no borders. If it finds a way to transfer from one place to another, it will!" 14 Only one of my informants, a public health specialist working at the Ministry of Health, was critical of this argument and suggested that the risk constituted by the Ebola epidemic in West Africa was exaggerated:

People said: "We live in a global village, it will affect us, so we have to spend Norwegian money from the Ministry of Health on the problem because we can be affected if they are affected" - which is just not true! [...] It was fairly unlikely that this [Ebola] would have a great impact here" 15

The willingness of the Norwegian authorities to recognize Ebola as a threat by invoking the argument "diseases know no borders' is not surprising. International relations scholars have argued that the emergence since the 1990s of a new global health security regime has largely been enabled by the widespread adoption of this argument (Davies, Kamradt-Scott, and Rushton 2015; McInnes and Lee 2012; Weir 2014; Nunes 2014; de Bengy Puyvallee and Kittelsen, forthcoming). They also found that this claim was crucial in creating a global problem out of the Ebola crisis and fostering collective action (McInnes 2016: 386). What is more, the perception of a borderless world has concrete political consequences, clearly visible in the Norwegian response to Ebola. This translates into a norm of rapid intervention to contain the outbreak at its source, integrating international measures as the first priority in national preparedness plans (Rushton 2011; Davies, Kamradt-Scott, and Rushton 2015). Norwegian health authorities seem to have widely adopted such a proactive, interventionist approach. An informant from the Institute of Public Health argued for instance that "it is clearly the responsibility of national public health institutes to work internationally when it comes to infection control", ${ }^{16}$ because only a proactive policy can effectively fulfil the Ministry of Health's mandate to ensure "society's security and preparedness in regard to health and health care sectors" (Health-Directorate 2016). An adviser from the Ministry of Health suggests nothing less:

\footnotetext{
${ }^{11}$ Interview, diplomat from the Norwegian Ministry of Foreign Affairs, 30 September 2016.

${ }^{12}$ Interview, staff member from the Norwegian Institute of Public Health, 13 September 2016.

${ }^{13}$ Interview, staff member from the Norwegian Research Council, 28 September 2016.

${ }^{14}$ Interview, staff member from the Norwegian Ministry of Health, 28 September 2016.

${ }^{15}$ Interview, staff member of the Norwegian Ministry of Health, 30 October 2016.

${ }^{16}$ Interview, staff member from the Norwegian Institute of Public Health, 13 September 2016.
} 
We have argued for a long time for the need to look also at the international dimension. Actions taken at the regional level [...] will have implications for what actions are necessary to implement at the national level - that's the starting point for our thinking in such emergencies. ${ }^{17}$

\section{Managing a scared public}

In addition to the health authorities' "responsibility to protect [their] own civilian population" 18 from dangerous pathogens, epidemics constitute a serious challenge for both the society and the state. On the one hand, epidemics highlight underlying values and exacerbate social predispositions, such as defiance against the state or inter-group conflict (Rosenberg 1989: 2). Old wounds from years of civil war and instability in the impacted countries reappeared with the epidemic, particularly in the form of mistrust in the government and conspiracy theories (Kamradt-Scott et al. 2015). On the other hand, outbreaks put considerable pressure on the state, which is held accountable for its management of the crisis, by both its national citizens and the international community. The government and public health authorities risk having their legitimacy questioned and losing the vital trust they have established with the population (Roalkvam and Jani 2013: 115-17). The worst-case scenario for a government is, of course, failing to protect the population and contain the outbreak, but overreacting might also take a great toll on its legitimacy (Lakoff 2008: 40-42). Epidemics are therefore a ticking bomb against which it is difficult to find an appropriate response.

In the case of the Ebola epidemic, I argue that the spectacular images of the volunteer's repatriation led to a visual securitization of the crisis (Hansen 2011: 569; McDonald 2008), shifting attitudes in the Norwegian public from neglect and a relative indifference (Nunes 2016) to a mix of fear and compassion. In other words, these images reinforced the credibility of the threat constituted by Ebola (McInnes and Rushton 2011: 118; Balzacq 2005: 181), leading to a perception of the epidemic as a direct security issue for Norway. Consequently, the government had to adopt a careful communication strategy to manage public opinion, insisting for instance on the low probability of the epidemic spreading to Norway (even though many in the administration believed this could become a serious threat). The government also had to demonstrate that it was active and on top of the situation. It announced its decision to send public health workers to Sierra Leone the day following the sick volunteer's repatriation (Health-Directorate 2015a: 5), precipitating the launch of a project planned since late-summer 2014. This led a senior adviser from the Ministry of Health to conclude that:

All politicians need to be seen as doing something. Handlekraft is what we call it in Norway [...] This was perceived as a huge threat at the time in West Africa,

\footnotetext{
${ }^{17}$ Interview, staff member from the Norwegian Ministry of Health, 28 September 2016.

${ }^{18}$ Interview, staff member from the Norwegian Directorate of Health, 5 April 2014.
} 
and what could we not do? we couldn't sit here doing nothing; so we had to do something; and what could we do? We could send people out to do something! I don't think the results even mattered! ${ }^{19}$

Indeed, the disappointing results of the field hospital project in Sierra Leone were never discussed in the public debate. The treatment facility, open for three and half months with a capacity of 100 beds (at a cost to Norway of no less than USD 15 million), only admitted 33 Ebola patients (of whom 18 died) (Health-Directorate 2015a: 50). Norway, I suggest, acted as a do-gooder during the Ebola crisis, "someone who does things that they think will help other people, although the other people might not find their actions helpful". ${ }^{20}$

Moreover if the government had to "do something" to legitimize itself and build trust, at the same time that it had to convince the public that this proactive policy would not backfire with the infection of health personnel sent abroad. The health authorities therefore centred their communication on the humanitarian nature of the operation, as well as its safety. Images of health workers wearing personal protective equipment were useful in this regard, illustrating the danger of the threat - and hence the legitimacy of a preventive policy to protect Norway - while showing the care provided to those suffering in West Africa (Pallister-Wilkins 2016).

\section{Solidarity and/or security? The partial securitization of Norway's Ebola response}

I have shown that the repatriation to Norway of a sick health worker not only gave unprecedented visibility to the ongoing humanitarian crisis in Sierra Leone, but also a worrying proximity to the threat. It triggered a strong governmental response, balancing different objectives and values: on the one hand, altruism and the provision of care for those suffering resonated with Norway's national identity and the country's humanitarian tradition; on the other hand, security concerns and self-interest echoed a narrative linking globalization with increased vulnerability and a serious risk of panic spreading among the population (Brown and Stovea 2014: 304; Davies 2008). The Norwegian Directorate of Health came to a similar conclusion in its report on the management of the Ebola crisis stating that "the motivations for the Norwegian contribution were thus both humanitarian and selfish" (Health-Directorate 2015a: 50). An informant from the same institution clarified this statement, describing the Ebola response as "a combination which you see in many situations at the moment: an element of humanitarian aid, which is very important, but balanced with civil protection issues". ${ }^{21}$ If undoubtedly, the Norwegian government had multiple motivations for contributing to international projects to fight Ebola; it transpires from my interviews that the "balance" between these different objectives seems to have shifted

\footnotetext{
${ }^{19}$ Interview, staff member of the Norwegian Ministry of Health, 30 October 2016.

${ }^{20}$ Cambridge Dictionary Online, http://dictionary.cambridge.org/dictionary/english/do-gooder

${ }^{21}$ Interview, staff member from the Norwegian Directorate of Health, 10 November 2016.
} 
in favour of the self-interest side of the response as the crisis developed, as suggested clearly by a source from the Civil Protection Agency:

I think we started with the idea of trying to help people affected in West Africa.

But of course, [...] the possibility that it would spread to Europe and to the United States, that affected the government's willingness to do something. I'm sure about that! ${ }^{22}$

Unlike accounts suggesting that the Ebola crisis was securitized (Huang 2014), i.e. the epidemic was considered an existential threat, I argue that the Norwegian response offers a case of "partial securitization" (McInnes and Rushton 2011: 127). To Colin McInnes and Simon Rushton, securitization is a "continuum" and can therefore be "partial"; "different audience members would place the issue at different points on the spectrum between normalcy and existential threat" (Ibid: 128). Indeed, a conflict between the Health Trust in charge of recruiting medical personnel to staff the field hospital opened in Sierra Leone and the Directorate of Health, operational leader of the project, suggests different approaches to the response and a gradual move towards securitization. Disagreements between the two institutions emerged in particular regarding the project's termination. The government wanted to end the project as soon as possible, i.e. when the outbreak seemed to be under control and no longer was an existential threat: "our goal was to be in and out, very quickly" confirmed a source at the Directorate of Health. ${ }^{23} \mathrm{~A}$ contrario, the Health Trust aimed to "pursue the Norwegian contribution in Moyamba for a minimum of a year or two [...] in a much lighter format". ${ }^{24}$ The organization advocated such an approach for two main reasons: first, the epidemiology of the outbreak was still uncertain, and the number of cases could have increased again; second, the local health system, decimated by the epidemic, needed longer-term support (HelseBergen 2015: 6; 21). Different intentions, and therefore different positions on the securitization continuum, explain the conflict between the two institutions. In the words of a bureaucrat from the Ministry of Health: "they had another purpose with the mission". ${ }^{25}$ The Health Trust, working directly with the volunteers, was driven mainly by the perspective of "international solidarity", as stated in its report (HelseBergen 2015: 62). It therefore rejected the government's partial securitization of the response, considering it a betrayal of the altruistic nature of the project - a reaction to be expected considering the ideal of purity contained in humanitarian action (Thieren 2007; Calhoun 2013: 52). A source at the Health Trust told me for instance:

\footnotetext{
${ }^{22}$ Interview, staff member from the Norwegian Directorate for Civil Protection, 26 October 2016, Emphasis added.

${ }^{23}$ Interview, staff member from the Norwegian Directorate of Health, 29 September 2016.

${ }^{24}$ Report from the Bergen Health Trust, HelseBergen 2015: 21 Translated from Norwegian by the author.

${ }^{25}$ Interview, staff member from the Norwegian Directorate of Health, 29 September 2016.
} 
The Directorate of Health advised the Ministry to stop the project as quickly as possible. When the threat to Norwegian citizens, for the Western part of Europe [...] was over, they just stopped the project immediately! I was very disappointed about that! [...] When we realized how this project finished, I felt kind of shameful that the perspective of international solidarity and altruism was taken away from us - and I'm very disappointed about that! ${ }^{26}$

The fact that different actors have still different opinions on whether the response should be securitized or not suggests a "partial securitization" of the Ebola crisis. In addition, it seems that the balance shifted towards security concerns as the crisis developed, although the humanitarian aspects of the response remained present throughout. This shift created resentment and a sense of being deceived amongst some of the actors directly involved, but interestingly, public opinion remained relatively indifferent as this was not debated in the national media.

\section{A universalist understanding of global health security?}

A blending of elements of idealpolitik (humanitarianism) and realpolitik (security concerns) in the Norwegian Ebola response makes it difficult to relate it to either a "statist" or "globalist" approach to global health security. The policy's altruistic framing, its legitimization as a moral obligation to provide assistance and its humanitarian objectives suggest a "globalist" approach to the Ebola crisis. However, the government's security concerns, the objective to protect Norway by adopting a proactive policy to contain the virus and the investment in research for medical countermeasures (a vaccine) correspond to the "statist" perspective's values and interests (Roemer-Mahler and Elbe 2016). I therefore suggest that the Norwegian Ebola response lies in a grey zone between "statist" and "globalist" perspectives, in a third way that I call a universalist approach to global health security. A universalist approach corresponds to an effort to reconcile altruistic and self-interested objectives; the priorities of developing and developed countries; the security of states and individuals, thus, the global.

These concerns are not new for Norway. The Oslo Ministerial Declaration (2007), initiated by France and Norway with the support of developing countries, represents an early attempt to find a balanced compromise between diverging challenges, interests and priorities (Davies 2010b: 1187; Møgedal and Alveberg 2010). This call to make global health a foreign policy issue addresses concerns from the "statist" approach to global health security (infectious diseases with pandemic potential), as well as from the "globalist" perspective (environmental challenges, development issues, trade policies). The underlying driving idea is that problems of the most vulnerable might become a threat to everyone, and that improvement of health anywhere in the world has thus positive consequences everywhere (Davies 2010a:

\footnotetext{
${ }^{26}$ Interview, staff member from the Bergen Health Trust, 22 December 2016.
} 
145). In the debates following the Ebola crisis, Norwegian Prime Minister Solberg has declared that "protecting the vulnerable is protecting ourselves" (Prime Minister Erna Solberg, quoted in: CEPI 2017) - the same argument advocated a decade ago. This universalist approach to global health security derives from the economic concept of global public goods, whereby health security is considered a good everyone enjoys (non-excludable) and improvements to which are beneficial to all (non-rival) (Ooms et al. 2017). Such a way of thinking opens possibilities to set up collective action based on partnerships between developing and developed countries, because after all, "there is nothing unjust about the aim of limiting the spread of infectious diseases" (Davies, Kamradt-Scott, and Rushton 2015: 135). It also allows a more nuanced analysis of actions taken in the name of global health security, that are often neither fully security driven, nor completely altruistic.

\section{Conclusion}

The Norwegian government's response to the Ebola crisis was largely influenced by the repatriation of an Ebola-infected health worker (context), that precipitated the recognition of the outbreak as a "crisis" and triggered a strong public response. This event generated an outpouring of solidarity and goodwill, putting pressure on the government to set-up a humanitarian response to fulfil a moral obligation to help (norm). Interestingly, it also raised security concerns amongst national health authorities, seeking a way to limit the epidemic's spread and manage rising fear amongst the public (interests). Confronting the context, norm and interests that shaped the policy (Wendt 1999: 139), I argue that the Norwegian government partly securitized its response to Ebola, allowing it to mobilize exceptional resources. This strategy met however resistance, particularly by volunteers who expressed frustration over unmet expectations on the nature of the response, suggesting that the response was only partially securitized. My analysis of the Norwegian Ebola response concurs thus with many studies pointing to the key role of security concerns in the global response to Ebola, but nuances them by highlighting other motives, such as a genuine desire to be in solidarity with affected countries and provide them with a benevolent assistance. I argue that the theoretical distinction between a "statist" and "globalist" approach to global health security does not do justice to the complexity of the Norwegian government's goals and values driving its response to Ebola. I therefore suggest a third way, a universalist understanding of global health security that takes the global as a referent for security and allows a compromise between idealpolitik and realpolitik. Although, if this universalist approach can be a useful analytical tool, it rests on a fragile balance of sometimes contradictory values and objectives and can therefore be difficult to operationalize. An expert on Norwegian global health policy, strongly driven by humanitarian ideals and sceptical of the US understanding of global health security - archetype of the "statist" approach warned for instance that: 
The whole concept [of global health security] is risky, and we need to know exactly what we are doing [...] One shouldn't follow big brother [the USA] in everything! ${ }^{27}$

\section{References}

Adams, Vincanne, Novotny, Thomas \& Leslie, Hannah (2008) “Global health diplomacy” Medical Anthropology, 27 (4): 315-323.

Aldis, William (2008) "Health security as a public health concept: a critical analysis" Health Policy and Planning, 23 (6): 369-375.

Balzacq, Thierry (2005) "The three faces of securitization: Political agency, audience and context" European Fournal of International Relations, 11 (2): 171-201.

Brown, Garrett Wallace, \& Stovea, Preslava (2014) "Reevaluating health security from a cosmopolitan perspective" in Simon Rushton \& Jeremy Youde (eds.), Routledge Handbook of Global Health Security. London \& New York: Routledge (304-317).

Brysk, Alison (2009) Global Good Samaritans: Human Rights as Foreign Policy: Oxford: Oxford University Press.

Calhoun, Craig (2013) "The idea of emergency: humanitarian action and global (dis)order" in Didier Fassin \& Mariella Pandolfi (eds.), Contemporary States of Emergency: The Politics of Military and Humanitarian Interventions Zone Books (29-58).

CDC (2014) "Questions and Answers: Estimating the Future Number of Cases in the Ebola Epidemic in Liberia and Sierra Leone, 2014-2015" [Press release]. Available at: http://www.cdc.gov/vhf/ebola/outbreaks/2014west-africa/qa-mmwr-estimating-future-cases.html

CEPI. (2017) "Global partnership launched to prevent epidemics with new vaccines" [Press release]. Available at: http://cepi.net/cepi-officially-launched

Dahl, Ann-Sofie (2005) "Sweden, once a moral superpower, always a moral superpower?" International fournal, 61 (4): 895-908.

Davies, Sara E. (2008) "Securitizing infectious disease” International Affairs, 84 (2): 295-313.

Davies, Sara. E. (2010a) Global politics of health Cambridge, England: Polity Press.

Davies, Sara. E. (2010b) "What contribution can International Relations make to the evolving global health agenda?" International Affairs, 86 (5): 1167-1190.

Davies, Sara. E., Kamradt-Scott, Adam \& Rushton, Simon (2015) Disease diplomacy: international norms and global health security: Johns Hopkins University Press.

de Bengy Puyvallee, Antoine, \& Kittelsen, Sonja (Forthcoming) “Disease knows no borders': Pandemics and the politics of global health security” in Kristian. Bjørkdahl \& Benedicte Carlsen (eds.), Pandemic, Publics and Politics: Pilgrave Pivot.

De Carvalho, Benjamin, \& Sande Lie, Jon Harald (2015) “A great power performance: Norway, status and the policy of involvement" in Benjamin De Carvalho \& Ivar B. Neumann (eds.), Small states and status seeking: Norway's quest for international standing Routledge (56-72).

Elbe, Stefan (2010) Security and global health: Polity. Cambridge \& Malden.

Hansen, Lene (2011) "Theorizing the image for security studies: visual securitization and the Muhammad Cartoon Crisis” European fournal of International Relations, 17 (1): 51-74.

Helsedirektoratet (2015a) Erfaringsgjennomgang av norsk ebolahåndtering. Available at: https://goo.gl/rWLns2.

Helsedirektoratet (2015b) "Hjelper alle, redder mange" [Press release]. Available at: https://helsedirektoratet. no/nyheter/hjelper-alle-redder-mange

Helsedirektoratet (2016) Norwegian Emergency Medical Teams. Utredning av tverrsektoriell beredskapsordning for akutte kriser.

Helse Bergen. (2015) Sluttrapport. Oppdrag til Helse Vest RHF om mobilisering av norsk helsepersonell for humitcer bistand $i$ Sierra Leone Available at: https://goo.gl/OXoWhs

Honigsbaum, Mark (2017) "Between Securitisation and Neglect: Managing Ebola at the Borders of Global Health” Medical History, 61 (2): 270-294.

${ }^{27}$ Interview with an expert of the Norwegian global health policy, 15 September 2016. 


\section{Norway's response to Ebola: balancing altruistic and security concerns}

Huang, Yanzhong (2014) “The Downside of Securitizing the Ebola Virus" Global Health Program. Available at: https:/www.cfr.org/expert-brief/downside-securitizing-ebola-virus

Kamradt-Scott, Adam (2016) "WHO's to blame? The World Health Organization and the 2014 Ebola outbreak in West Africa" Third World Quarterly, 37 (3): 401-418.

Kamradt-Scott, Adam, Harman, Sophie, Wenham, Claire, \& Smith, Frank (2015) "Saving Lives: The civilmilitary response to the 2014 Ebola outbreak in West Africa". The University of Sidney. Available at: https:// sydney.edu.au/arts/ciss/downloads/SavingLivesPDF.pdf

Lakoff, Andrew (2008) "From Population to Vital System: National security and the changing object of public health" in Andrew Lakoff \& SStephen Collier (eds.), Biosecurity Interventions. New York: Columbia University Press (33-60).

Lakoff, Andrew (2017) Unprepared. Global Health in a time of emergency. University of California Press.

Lamont, Christopher (2015) Research Methods in International Relations. Sage.

Lancaster, Carol (2007) Foreign Aid. Diplomacy, Development, Domestic Policy. Chicago \& London: The University of Chicago Press.

Leira, Halvard et al (2007) "Norske selvbilder og norsk utenrikspolitikk" Norsk utenrikspolitisk institutt, april 2007:1-46.

McDonald, Matt (2008) "Securitization and the construction of security" European fournal of International Relations, 14 (563): 563-587.

McInnes, Colin (2014) "The Many meanings of health security" in Simon Rushton \& Jeremy Youde (eds.), Routledge handbook of global health security. London og New York: Routledge (7-17).

McInnes, Colin (2016) "Crisis! What crisis? Global health and the 2014-15 West African Ebola outbreak" Third World Quarterly, 37 (3): 380-400.

McInnes, Colin \& Lee, Kelley (2006) "Health, security and foreign policy" Review of International Studies, 32 (1): 5-23.

McInnes, Colin \& Lee, Kelley (2012) Global Health and International Relations: Polity Press.

McInnes, Colin \& Rushton, Simon (2010) "HIV, AIDS and security: where are we now?" International Affairs, 86 (1): 225-245.

McInnes, C., \& Rushton, Simon (2011) "HIV/AIDS and securitization theory" European fournal of International Relations, 19 (1): 115-138

Møgedal, Sigrun, \& Alveberg, Benedikte Louise (2010) “Can Foreign Policy Make a Difference to Health?" PLOS Medicine, 7 (5).

NORAD (2010) Norwegian humanitarian response to natural disasters. Case of Haiti Earthquake Fanuray 2010. Available at: https://goo.gl/OhCjrN.

Nunes, Joao (2014) "Questioning health security: Insecurity and domination in world politics" Review of International Studies, 40 (5): 939-960.

Nunes, Joao (2016) "Ebola and the production of neglect in global health" Third World Quarterly, 37 (3): 542-556.

Ooms, Gorik, Claudia Beiersmann, Walter Flores, Johanna Hanefeld, Olaf Müller, Moses Mulumba, Trygve Ottersen, Malabika Sarker, og Albrecht Jahn (2017) "Synergies and tensions between universal health coverage and global health security: why we need a second 'Maximizing Positive Synergies' initiative". BMF Global Health, 2.

Pallister-Wilkins, Polly (2016) "Personal Protective Equipment in the humanitarian governance of Ebola: between individual patient care and global biosecurity" Third World Quarterly, 37(3), 507-523.

Reus-Smit, Christian (1999) The moral purpose of the state: culture, social identity, and institutional rationality in international relations. Princeton, N.J: Princeton University Press.

Roalkvam, Sidsel, \& Jani, Jagrati (2013) "Rights and obligations in national health governance" in Sidsel Roalkvam, Desmond McNeill, \& Stuart Blume (eds.), Protecting the World's Children: Immunisation policies and Practices Oxford (115-147).

Roemer-Mahler, Anne, \& Elbe, Stefan (2016) "The race for Ebola drugs: pharmaceuticals, security and global health governance" Third World Quarterly, 37 (3): 487-506.

Roemer-Mahler, Anne \& Rushton, Simon (2016) "Introduction: Ebola and International Relations" Third World Quarterly, 37 (3): 373-379.

Rosenberg, Charles (1989) "What is an epidemic? AIDS in historical perspective" Daedalus, 118 (2): $1-17$.

Rushton, Simon (2011) “Global Health Security: Security for Whom? Security from What?” Political Studies, 59 (4): 779-796. 


\section{Antoine de Bengy Puyvallée}

Rushton, Simon, \& Youde, Jeremy (2015) Routledge handbook of global health security. Routledge/Taylor \& Francis Group.

Stokke, Olav (1989) Western middle powers and global poverty: the determinants of the aid policies of Canada, Denmark, the Netherlands, Norway and Sweden (Vol. 64). Uppsala: The Scandinavian Institute of African Studies in cooperation with The Norwegian Institute of International Affairs.

Stortinget. (2014) Sak nr. 4: Redegjørelse av utenriksministeren og helse- og omsorgsministeren om smitteutbruddet av ebola $i$ Vest-Afrika. Available at: https:/goo.gl/MqvADk.

Thieren, Michel (2007) "Health and foreign policy in question: the case of humanitarian action" World Health Organization. Bulletin of the World Health Organization, 85 (3): 218-224.

Tvedt, Terje (2007) "International Development Aid and Its Impact on a Donor Country: A Case Study of Norway" The European fournal of Development Research, 19 (4): 614.

UD (2014a) "Norge bidrar til å stanse Ebola-utbruddet i Guinea" [Press release]. Available at: https://www. regjeringen.no/no/aktuelt/ebola-utbrudd/id755278/

UD (2014b) "Norway doubles support for fight against Ebola" [Press release]. Available at: https://www. regjeringen.no/en/aktuelt/fight_ebola/id2005373/

UD (2014c) "Norway increases funding to combat the Ebola outbreak in West Africa" [Press release]. Available at: https:/www.regjeringen.no/en/aktuelt/Norway-increases-funding-to-combat-the-Ebola-outbreak-inWest-Africa-/id765521/

UD (2014d) "Norway pledges NOK 70 million to new World Bank fund to fight Ebola" [Press release]. Available at: https://www.regjeringen.no/en/aktuelt/fund_ebola/id2005813/

UD (2014e) "Norway trebles funding to combat Ebola" [Press release]. Available at: https://www.regjeringen. no/en/aktuelt/ebola_fundings/id2000878/

UD (2014f) "Norwegian Foreign Minister in Liberia: Norway pledges a further NOK 75 million to the fight against Ebola" [Press release]. Available at: https://goo.gl/N5JrfQ

UD (2015a) “Norway adjusts its Ebola response” [Press release]. Available at: https://www.regjeringen.no/en/ aktuelt/ebola-response/id2403173/

UD (2015b) "Norway increases humanitarian support to Nepal" [Press release]. Available at: https://www. regjeringen.no/en/aktuelt/nepal_support/id2425035/

UNSC (2014) Resolution 2177, adopted by the Security Council at its 7268th meeting, on 18 September 2014. Available at: http://www.ifrc.org/docs/IDRL/UN\%20SC\%20Res.pdf

Weir, Lorna (2014) "Inventing global health security, 1994-2005" in Simon Rushton \& Jeremy Youde (eds.), Routledge handbook of global health security London \& New York: Routledge (18-31).

Wendt, Alexander (1999) Social Theory of International Politics: Cambridge University Press.

WHO (2016a) "Ebola data and statistics" Available at: http://apps.who.int/gho/data/view.ebola-sitrep. ebola-summary-20160511?lang=en

WHO (2016b) "Ebola Response Funding - Donor contribution to WHO's Ebola response as of April 2016" [Press release]. Available at: http:/www.who.int/csr/disease/ebola/funding/en/ 